\title{
Wind Turbine Safety and Function Test Report for the Gaia-Wind 11-kW Wind Turbine
}

Technical Report NREL/TP-500-46724 January 2010

A. Huskey, A. Bowen, and D. Jager

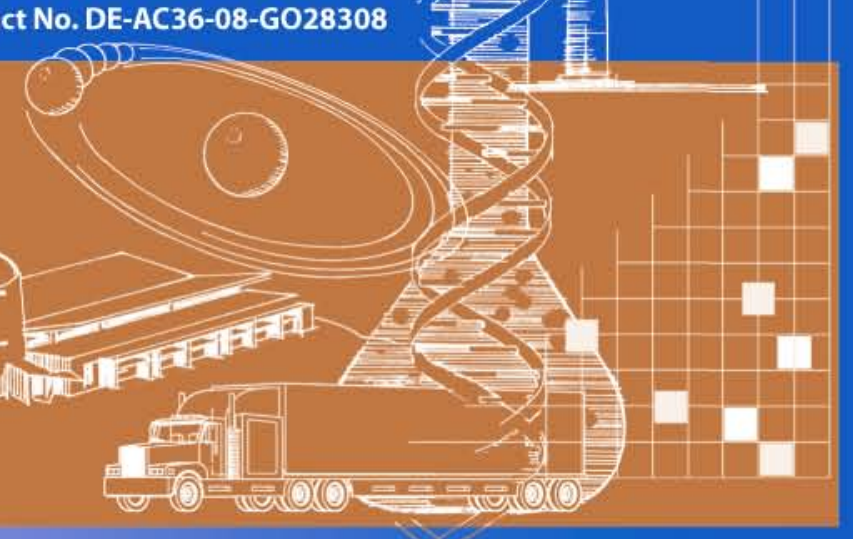




\section{Wind Turbine Safety and Function Test Report for the Gaia-Wind 11-kW Wind Turbine}

\section{A. Huskey, A. Bowen, and D. Jager}

Prepared under Task No. WER94501

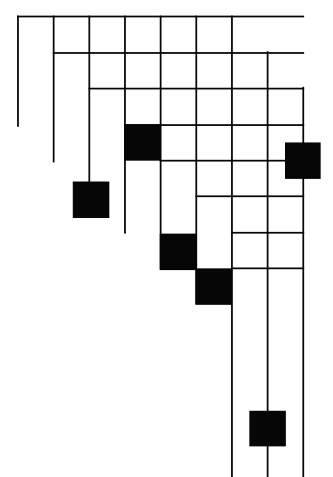




\section{NOTICE}

This report was prepared as an account of work sponsored by an agency of the United States government. Neither the United States government nor any agency thereof, nor any of their employees, makes any warranty, express or implied, or assumes any legal liability or responsibility for the accuracy, completeness, or usefulness of any information, apparatus, product, or process disclosed, or represents that its use would not infringe privately owned rights. Reference herein to any specific commercial product, process, or service by trade name, trademark, manufacturer, or otherwise does not necessarily constitute or imply its endorsement, recommendation, or favoring by the United States government or any agency thereof. The views and opinions of authors expressed herein do not necessarily state or reflect those of the United States government or any agency thereof.

Available electronically at http://www.osti.gov/bridge

Available for a processing fee to U.S. Department of Energy and its contractors, in paper, from:

U.S. Department of Energy

Office of Scientific and Technical Information

P.O. Box 62

Oak Ridge, TN 37831-0062

phone: 865.576 .8401

fax: 865.576 .5728

email: mailto:reports@adonis.osti.gov

Available for sale to the public, in paper, from:

U.S. Department of Commerce

National Technical Information Service

5285 Port Royal Road

Springfield, VA 22161

phone: 800.553.6847

fax: 703.605.6900

email: orders@ntis.fedworld.gov

online ordering: http://www.ntis.gov/ordering.htm 


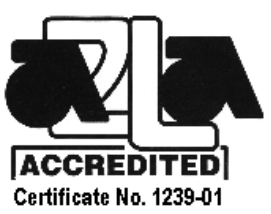

\section{Notice}

This report was prepared by the National Renewable Energy Laboratory (NREL), operated for the United States Department of Energy (DOE) by the Alliance for Sustainable Energy, LLC (Alliance), as an account of work sponsored by the United States government. The test results documented in this report define the characteristics of the test article as configured and under the conditions tested.

This report is provided "as is" and neither the government, Alliance, NREL, nor any of their employees makes any warranty, express or implied, including the warranties of merchantability and fitness for a particular purpose, or assumes any legal liability or responsibility for the accuracy, completeness, or usefulness of any such information disclosed in the report, or of any apparatus, product, or process disclosed, or represents that its use would not infringe privately owned rights.

Neither Alliance nor the United States government shall be liable for special, consequential, or incidental damages. Reference herein to any specific commercial product, process, or service by trade name, trademark, manufacturer, or otherwise does not necessarily constitute or imply its endorsement, recommendation, or favoring by the United States government or any agency thereof. The views and opinions of the authors expressed herein do not necessarily state or reflect those of the United States government or any agency thereof or Alliance.

NREL is a DOE Laboratory and, as an adjunct of the United States government, cannot certify wind turbines. The information in this report is limited to NREL's knowledge and understanding as of this date.

NREL is accredited by the American Association for Laboratory Accreditation (A2LA) and the results shown in this test report have been determined in accordance with the NREL's terms of accreditation unless stated otherwise in the report.

This report shall not be reproduced, except in full, without the written approval of Alliance or successor operator of NREL.

Approval By:

Arlinda Huskey, NREL Test Engineer Date

Approval By:

Jeroen van Dam, NREL Test Engineer Date 


\section{List of Acronyms}

AWG

DOE

NREL

NWTC

SWT
American Wire Gauge

United States Department of Energy

National Renewable Energy Laboratory

National Wind Technology Center

small wind turbine 


\section{Table of Contents}

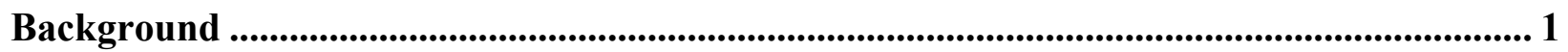

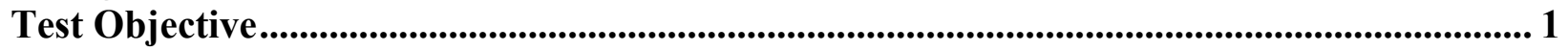

Description of Test Turbine and Setup .................................................................................. 1

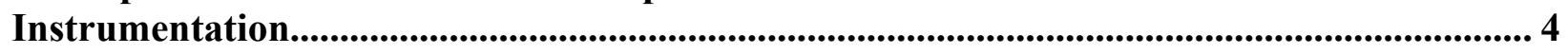

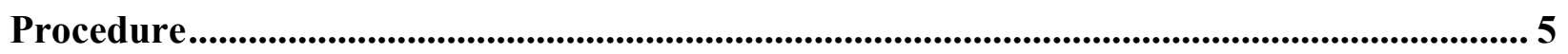

Control and Protection System Functions ................................................................. 5

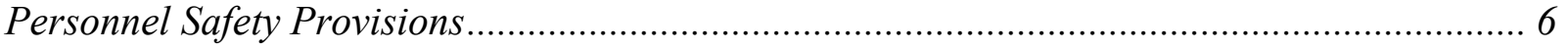

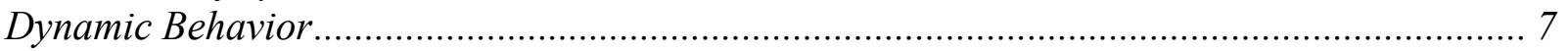

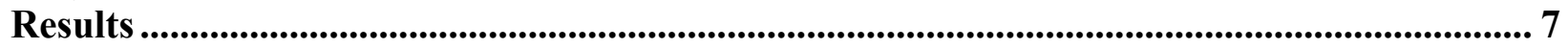

Control and Protection System Functions ..................................................................... 7

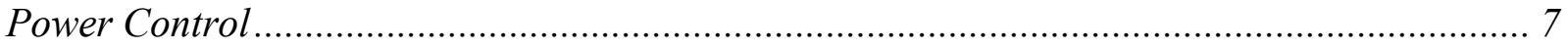

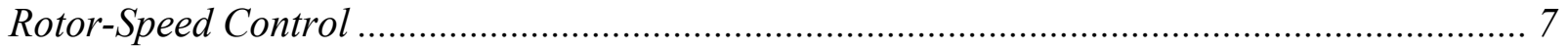

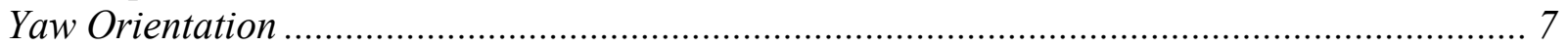

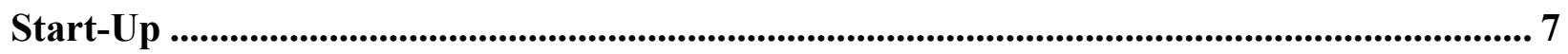

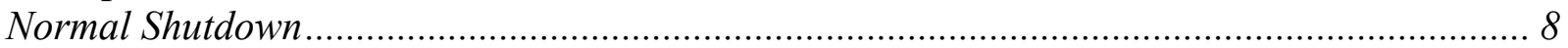

Emergency Shutdown from Any Operating Condition During Operation ............................. 8

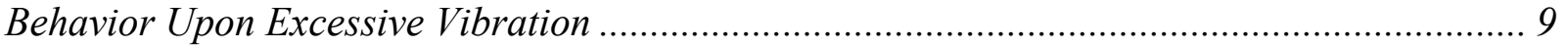

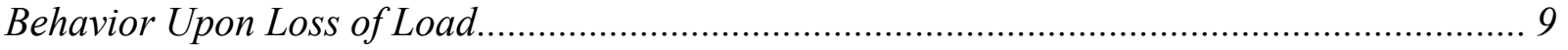

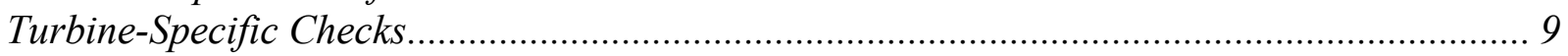

Personnel Safety Provisions ............................................................................................................. 10

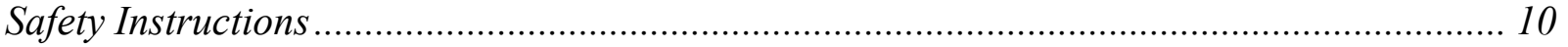

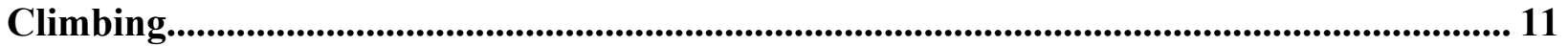

Standing Places, Platforms, and Floors..................................................................... 11

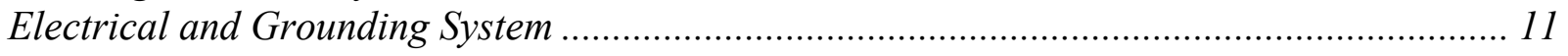

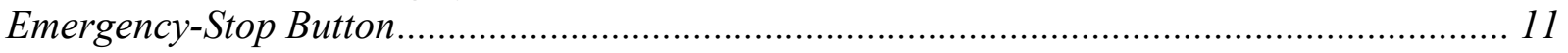

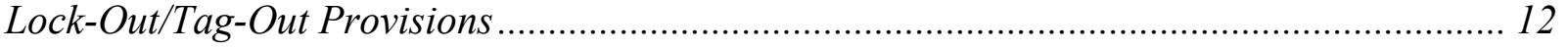

Interlock on Electrical Cabinets ...................................................................................... 12

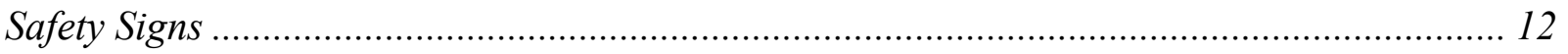

Presence and Functioning of Rotor Lock and Yaw Lock ............................................. 12

Unauthorized Changing of Control Settings ................................................................ 12

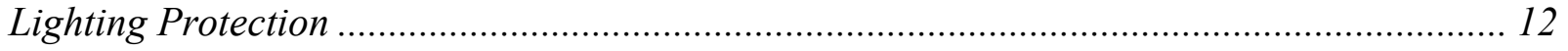

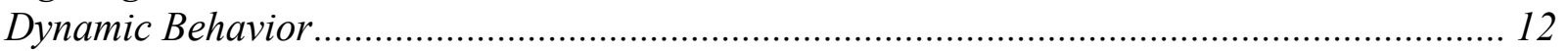

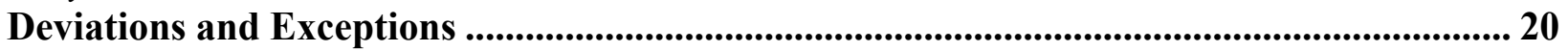

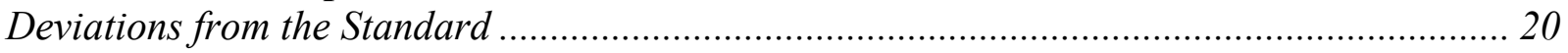

Exceptions to the NWTC Quality Assurance System ............................................................ 20

Appendix A. Instrument Calibration Sheets .............................................................................. 21 


\section{List of Figures}

Figure 1. Gaia-Wind 11-kW wind turbine at the National Wind Technology Center test site....... 3

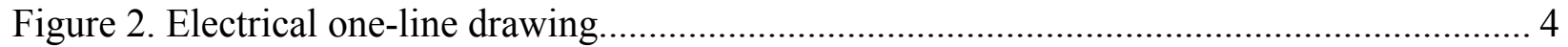

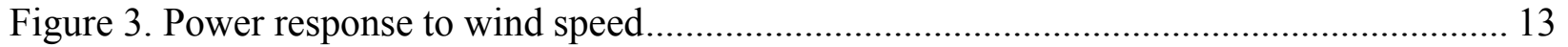

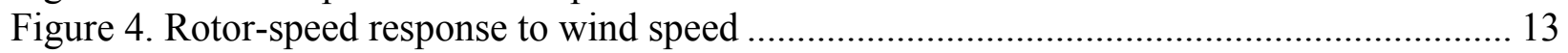

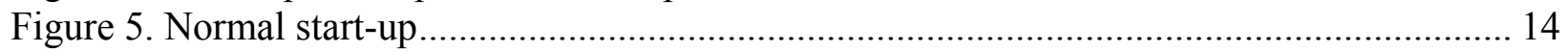

Figure 6. Turbine shutdown and auto-start after high-wind shutdown......................................... 14

Figure 7. Normal shutdown in wind speeds decreasing to less than cut-in ................................. 15

Figure 8. Automatic shutdown from over speed at design wind speed or greater........................ 15

Figure 9. Normal start-up after fault clearance at design wind speed or greater ........................... 16

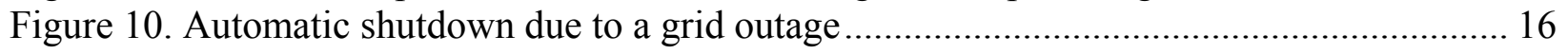

Figure 11. Automatic shutdown due to $10 \%$ rotor over speed ................................................... 17

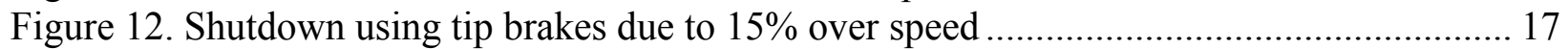

Figure 13. Automatic shutdown due to instant generator overcharge ......................................... 18

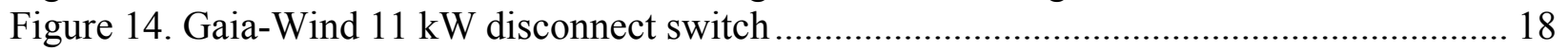

Figure 15. Gaia-Wind $11 \mathrm{~kW}$ emergency-stop button and main switch....................................... 19

Figure 16. Power and instrumentation cables from turbine to controller .................................... 19

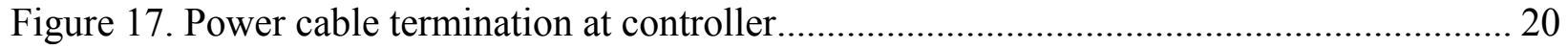

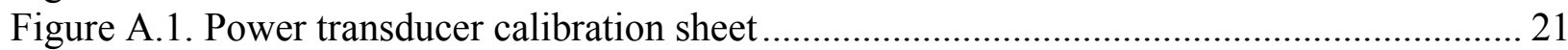

Figure A.2. Primary anemometer calibration sheet ................................................................. 22

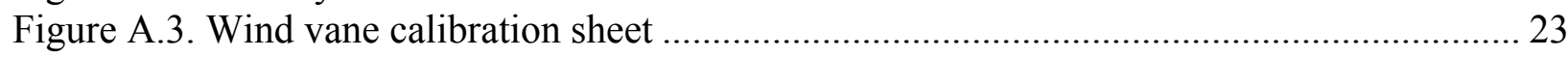

Figure A.4. National Instruments 9229 data-acquisition module calibration sheet I ................... 24

Figure A.5. National Instruments 9217 data-acquisition module calibration sheet I ................... 25

Figure A.6. National Instruments 9205 data-acquisition module calibration sheet I .................... 26

Figure A.7. National Instruments 9229 data-acquisition module calibration sheet II .................. 27

Figure A.8. National Instruments 9217 data-acquisition module calibration sheet II .................. 28

Figure A.9. National Instruments 9205 data-acquisition module calibration sheet II ................... 29

\section{List of Tables}

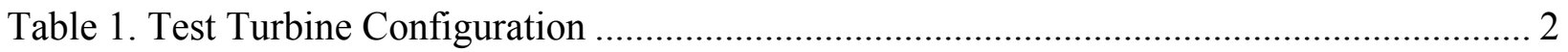

Table 2. Equipment List for Safety and Function Test............................................................. 4 


\section{Background}

This test was conducted as part of the U.S. Department of Energy's (DOE) Independent Testing project. This project was established to help reduce the barriers to wind energy expansion by providing independent testing results for small wind turbines (SWT). In total, four turbines were tested at the National Wind Technology Center (NWTC) as a part of this project. Safety and function testing is one of up to five tests performed on the turbines, including power performance, duration, noise, and power-quality tests. The results of the testing provide the manufacturers with reports that can be used for small wind turbine certification.

The test equipment includes a Gaia-Wind 11-kW wind turbine mounted on an 18-m monopole tower. Gaia-Wind Ltd. manufactured the turbine in Denmark. The system was installed by the NWTC site operations group with guidance and assistance from Gaia-Wind.

\section{Test Objective}

The objective of this test was to:

- Verify whether the test turbine displays the behavior predicted in the design;

- Determine whether provisions relating to personnel safety are properly implemented; and

- Characterize the dynamic behavior of the wind turbine at rated wind speed and greater speeds.

The National Renewable Energy Laboratory (NREL) does not limit safety and function tests to features described in the wind turbine documentation, and NREL also inspects - possibly tests - and reports on features that are required by IEC 61400-2 and that might not be described in the wind turbine documentation. NREL conducted this test in accordance with Section 9.6 of the IEC standard, "Wind Turbines-Part 2: Design Requirements for Small Wind Turbines," IEC 61400-2, second edition, 2006-03.

\section{Description of Test Turbine and Setup}

The test turbine was a Gaia-Wind $11-\mathrm{kW}$ wind turbine. This turbine is a downwind, twobladed, constant-speed, turbine with a rated power of $11-\mathrm{kW}$. Figure 1 shows the test turbine installed at the National Wind Technology Center. Table 1 provides the key descriptive information of the test turbine. 
Table 1. Test Turbine Configuration

\begin{tabular}{|l|l|}
\hline $\begin{array}{l}\text { Turbine manufacturer name } \\
\text { and address }\end{array}$ & $\begin{array}{l}\text { Gaia-Wind Ltd. } \\
\text { 1 Ainslie Road, Hillington Park } \\
\text { Glasgow G52 4RU } \\
\text { United Kingdom }\end{array}$ \\
\hline Model name & Gaia-Wind 11-kW \\
\hline Serial number & 10711114 \\
\hline Revision number & 114 \\
\hline Production date & 2007 \\
\hline Design nominal voltage at terminals (VAC) & 480 \\
\hline Maximum current at terminals $(\mathrm{A})$ & 20.9 \\
\hline Design frequency at terminals $(\mathrm{Hz})$ & 60 \\
\hline Small wind turbine (SWT) class & III \\
\hline Design 50-year extreme wind speed, $\mathrm{V}_{\mathrm{e} 50}(\mathrm{~m} / \mathrm{s})$ & 52.5 \\
\hline Rotor diameter (m) & 13 \\
\hline Hub height (vertical center of rotor) $(\mathrm{m})$ & 18.2 \\
\hline Tower type & Tubular \\
\hline Rated electrical power $(\mathrm{kW})$ & 11 \\
\hline $\begin{array}{l}\text { Rated wind speed (m/s) (slowest wind speed } \\
\text { at which turbine produces rated power) }\end{array}$ & 9.5 \\
\hline $\begin{array}{l}\text { Rated rotor speed (rpm) (slowest rotor speed } \\
\text { at which turbine produces rated power) }\end{array}$ & 60 \\
\hline Rotor speed range (rpm) & $60-62$ \\
\hline Fixed or variable pitch & Fixed blade, variable tip \\
\hline Number of blades & 2 \\
\hline Blade pitch angle (deg) & $\begin{array}{l}21 \text { degrees at 1.4 m radius, } 0 \text { degrees at } \\
6.5 \text { meter radius }\end{array}$ \\
\hline Blade make, type, serial number & $\begin{array}{l}\text { Gaia-Wind T202, glass fiber, centrifugally } \\
\text { activated tip brake, 2007/22 }\end{array}$ \\
\hline Description of control system (device \& software version) & Gaia-Wind IC-1000 Controller \\
\hline
\end{tabular}

The Gaia-Wind 11-kW wind turbine was installed at site $3.3 \mathrm{~b}$ at the NWTC, which is located 8 miles south of Boulder, Colorado. The site's terrain primarily is flat with short vegetation. The test site has prevailing wind bearing 292 degrees relative to true north. For measurements requiring highly accurate wind-speed data, NREL used data obtained when the wind direction was between 257 degrees true to 332 degrees true and 147 degrees true to 197 degrees true. In this measurement sector-which was established in accordance with IEC 61400-12-1 - the influence of terrain and obstructions on the anemometer and turbine is slight.

Figure 2 shows the general electrical arrangement. The wire run from the base of the tower to the data shed is approximately 64 meters of \#6 American Wire Gauge (AWG) wire. Inside the data shed, on the turbine side of the transformer, is a disconnect switch and a breaker panel. The transformer steps-up the voltage to $13.2 \mathrm{kV}$ for the grid. 


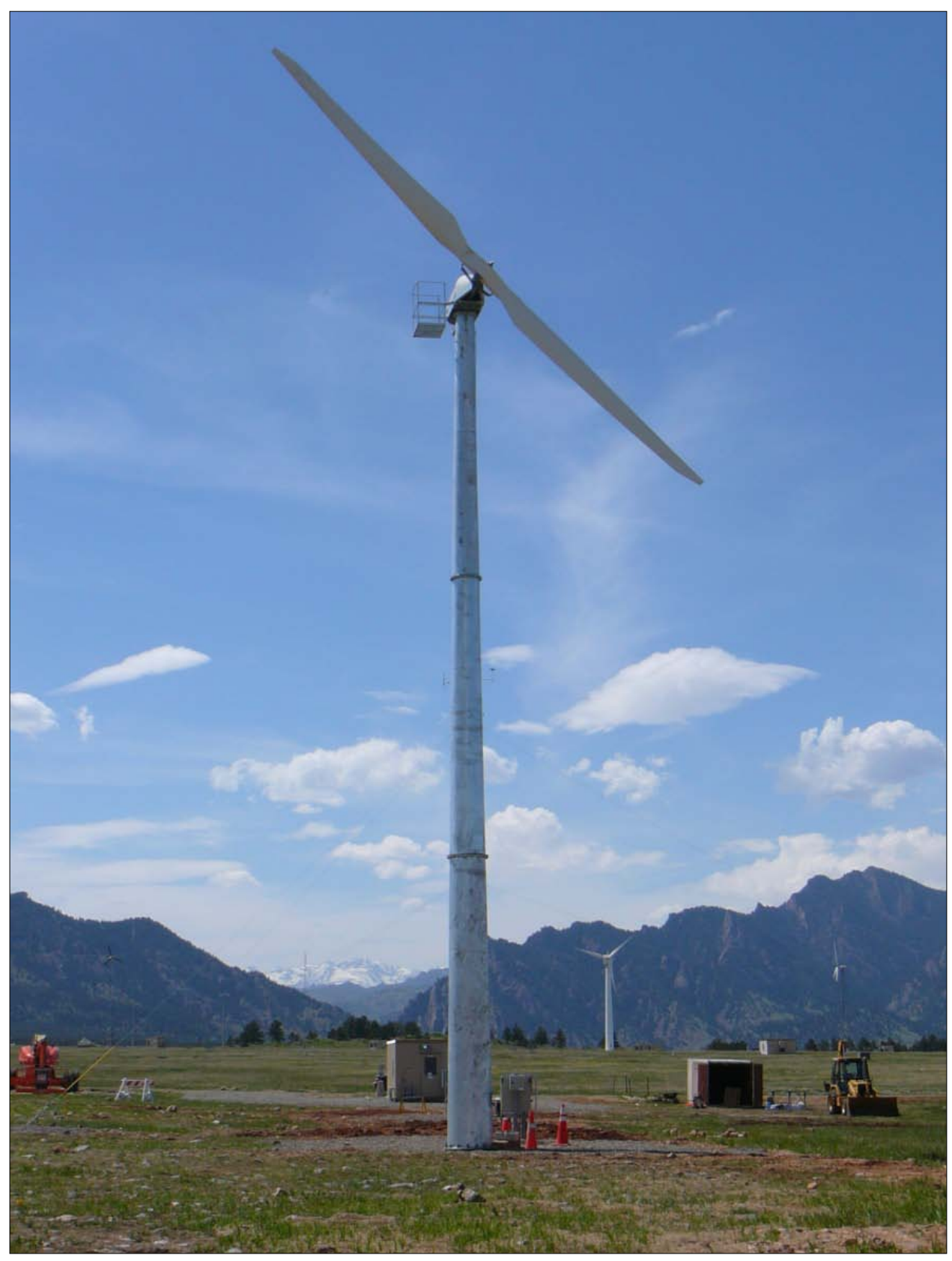

Figure 1. Gaia-Wind 11-kW wind turbine at the National Wind Technology Center test site 


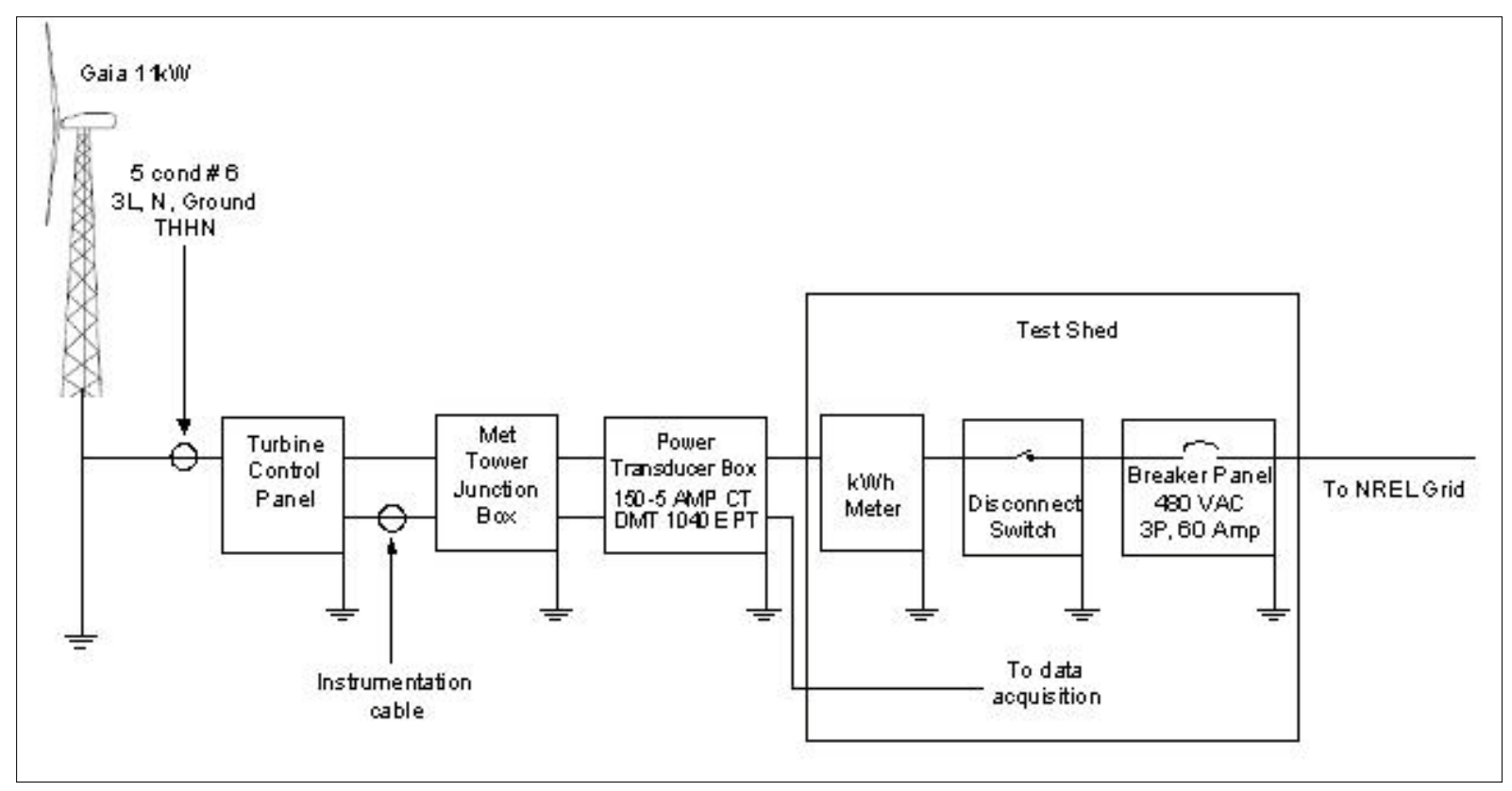

Figure 2. Electrical one-line drawing

\section{Instrumentation}

The following parameters were measured in this test: wind speed, electrical power, rotor speed, and grid voltage. The rotor speed was calculated by measuring the frequency of an optically isolated signal from the proximity sensor on the turbine generator. An indication of turbine status was obtained by measuring the status of the relay that indicates whether the turbine's brake is on. The instruments used for these measurements are listed in Table 2. The calibration sheets for the instruments used for this safety and function test are included in Appendix A.

Table 2. Equipment List for Safety and Function Test

\begin{tabular}{|c|c|c|c|}
\hline Instrument & Make, Model & Serial Number & Calibration Due Date \\
\hline Power transducer & $\begin{array}{l}\text { Ohio Semitronics, } \\
\text { DMT 1040E }\end{array}$ & 06091046 & February 15, 2010 \\
\hline $\begin{array}{l}\text { Current } \\
\text { transformers }\end{array}$ & $\begin{array}{l}\text { Ohio Semitronics, } \\
12974\end{array}$ & $\begin{array}{l}001293045 \\
001235428 \\
001293049\end{array}$ & Calibrated with power transducer \\
\hline $\begin{array}{l}\text { Primary } \\
\text { anemometer }\end{array}$ & Thies, First Class & 0707890 & April 7, 2009 \\
\hline $\begin{array}{l}\text { Reference } \\
\text { anemometer }\end{array}$ & NRG, Max 40 & 179500049023 & In situ \\
\hline Wind vane & $\begin{array}{l}\text { Met One, 020C with } \\
\text { Aluminum Vane }\end{array}$ & $\mathrm{X} 4357$ & April 7, 2009 \\
\hline $\begin{array}{l}\text { Data acquisition } \\
\text { system }\end{array}$ & $\begin{array}{l}\text { Compact DAQ w/LabView } \\
\text { cDAQ backplane } \\
\text { NI } 9229 \\
\text { NI } 9217 \\
\text { NI } 9205\end{array}$ & $\begin{array}{l}\text { 12E4DA3 } \\
\text { 12CBC7A } \\
\text { 12BFEE2 } \\
12 \mathrm{E} 9 \mathrm{C} 99\end{array}$ & $\begin{array}{l}\text { August } 14,2008 \\
\text { July } 20,2008 \\
\text { October } 8,2008 \\
\text { Modules post-test calibrated on May } \\
5,2009 \text {, found in compliance }\end{array}$ \\
\hline
\end{tabular}




\section{Procedure}

Safety and function testing can involve some risk to personnel and to equipment. By incorporating appropriate controls into testing procedures, NREL endeavors to accomplish its tasks with minimal risk. This test report documents these controls in areas where they might have influenced the results obtained.

\section{Control and Protection System Functions}

The first part of the test procedure is assessing the control and protection system functions (listed below). The turbine's response is observed for each major response category (start-up, normal shutdown, emergency shutdown) in the list below. For the cases in which faults or other actions cause one of these major responses, NREL staff simulates the appropriate input and verifies that the control and protection system appropriately sensed the condition and provided an indication of the appropriate response. This procedure, for example, enables generator overcharge functions to be checked without exposing the turbine to multiple potentially damaging stops. In the list below, these items are designated by the term "behavior."

1. Power control

2. Rotor-speed control

3. Yaw control

4. Start-up

a. Normal operation - wind speed greater than cut-in

b. Normal operation - wind speed decreasing to less than cut-out

c. After maintenance or fault clearance at design wind speed or greater

5. Normal shutdown under

a. Normal operation - wind speed decreasing to less than cut-in

b. Normal operation - wind speed increasing to greater than cut-out

i. Instantaneous reading greater than cut-out

ii. Behavior upon average reading when greater than cut-out

c. Maintenance or fault conditions at design wind speed or greater

6. Emergency shutdown during operation from any operating condition including:

a. Emergency stop in wind speeds less than design wind speed;

b. Emergency stop at design wind speed or greater;

c. Behavior upon automatic shutdown from over speed at design wind speed or greater; and

d. Behavior upon automatic shutdown from other fault (average generator overcharge) at design wind speed or greater.

7. Behavior upon excessive vibration 
8. Behavior upon loss of load
a. Response to grid outage
b. Response to grid instability (Overvoltage)

9. Turbine-specific checks
a. Behavior upon rotor over speed of $10 \%$
b. Behavior upon rotor over speed of $15 \%$
c. Behavior upon generator instantaneous overcharge
d. Behavior upon generator average overcharge
e. Behavior upon cable twist

\section{Personnel Safety Provisions}

The second part of the test procedure was to evaluate provisions for personnel safety. For the test turbine the following issues were reviewed.

1. Safety instructions
a. Safety instructions must be available for everybody working or operating at the site or in the wind turbine.
b. Safety instructions must cover installation, operation, and maintenance activities.

2. Climbing facilities must be checked for proper assembly and full function.
a. Tower climbing cable or equivalent
b. Tie-off points on outside of nacelle

3. Standing places, platforms, and floors
a. Trip hazards must be avoided or marked clearly.
b. Platforms, floors, and walkways must be equipped with nonslip surfaces.
c. Hatches in the platforms must be lockable.

4. Electrical and grounding system

5. Emergency-stop buttons

6. Lock-out/tag-out provisions

7. Interlock on electrical cabinets

8. Presence and functioning of rotor lock and yaw lock

9. Unauthorized changing of control settings

10. Lightning protection

11. Safety signs 


\section{Dynamic Behavior}

NREL staff observed the turbine at all operating wind speeds to note the dynamic behavior of the turbine, including (but not limited to) vibration, yaw, and noise.

\section{Results}

\section{Control and Protection System Functions}

The turbine exhibited no unexpected or inherently unsafe behavior during this investigation; however, this does not mean that the turbine is safe under all conditions. NREL limited testing to investigation of single-fault failures and has not investigated failures of "safe life" components. ${ }^{1}$ If a second fault occurs during a critical event, unsafe results could occur. Neither NREL nor the IEC turbine-design requirements make judgments on whether such failures are likely or whether additional features in the control and protection system are needed to protect against such consequences.

\section{Power Control}

Power measurements over the test period indicate that the turbine system exhibited control over power production in response to high winds. Both 1-minute average power data and 1second maximum power data in Figure 3 show a leveling in wind speeds greater than about $12 \mathrm{~m} / \mathrm{s}$ to $13 \mathrm{~m} / \mathrm{s}$. Furthermore, the turbine automatically shuts down if the average wind speed over 10 minutes is at least $20 \mathrm{~m} / \mathrm{s}$, and on occurrence of an instantaneous reading of at least $25 \mathrm{~m} / \mathrm{s}$.

\section{Rotor-Speed Control}

Rotor-speed measurements over the test period indicate that the turbine system exhibits control over rotor speed in response to high winds. Figure 4 shows both 1-minute average and 1 -second maximum rotor speed. The maxima level off and hold at about $63 \mathrm{rpm}$. The manufacturer's rated rotor speed is $60 \mathrm{rpm}$ and a rotor over speed occurs at $66 \mathrm{rpm}$. The data shows the rotor speed was held at less than $66 \mathrm{rpm}$.

\section{Yaw Orientation}

NREL staff observed yaw behavior frequently during the test period and compared yaw position with the nearby wind-vane indication of wind direction. Normal behavior was observed under all operating wind conditions. The turbine has cables that run from the nacelle through the tower and does not use slip rings. A test for simulating the turbine's response to twisted power and instrumentation cables is provided elsewhere in this section.

\section{Start-Up}

Normal Operation-Wind Speed Greater Than Cut-In. This event was captured in January 2009. As shown in Figure 5, the wind speeds were slightly greater than the cut-in wind speed,

\footnotetext{
${ }^{1}$ The IEC turbine design standard, IEC 61400-1, defines "safe life" as those components for which the designer has "prescribed a service life with a declared probability of failure." These typically are components that transmit wind loads to the ground, such as blades, hubs, low-speed shafts, main bearings, main frames, yaw bearings, towers, and foundations. Failure of any of these components could lead to a catastrophic failure of the turbine, therefore each component should be designed with an appropriate safety factor. NREL has not evaluated these design characteristics and makes no judgment on whether appropriate safety factors have been used.
} 
so the turbine started from the "soft starter." This is indicated by the negative power spikes that occurred before starting. During the turbine motoring pulses, the rotor speed increased and the turbine began producing power in wind speeds of approximately $4 \mathrm{~m} / \mathrm{s}$. NREL staff observed similar smooth cut-ins when the turbine was returned to service after shutdown.

Normal Operation-Wind Speed Decreasing to Less Than Cut-Out. This event was documented in November 2008. Figure 6 shows the turbine shutting down due to an instantaneous wind-speed reading of more than $25 \mathrm{~m} / \mathrm{s}$ as the rotor speed and power fall to zero. After approximately 20 minutes the wind speeds decreased and turbine auto-started without error.

After Maintenance or Fault Clearance at Design Wind Speed $(10.5 \mathrm{~m} / \mathrm{s})$ or Greater. This event occurred in January 2009. The "emergency-stop" button on the side of the controller box was pressed, activating the mechanical brake to stop the turbine. The error was cleared manually and the turbine started without problem. Figure 9 shows a time series of the events.

\section{Normal Shutdown}

Normal Operation-Wind Speed Decreasing to Less Than Cut-In. This event was captured in January 2009. When the wind speed decreases to less than cut-in the turbine stops producing power-with no significant change in sound or behavior. The turbine allows the rotor to freewheel in wind speeds less than cut-in. Figure 7 shows that the turbine stopped producing power and slowed to a stop as the wind speed decreased.

Normal Operation-Wind Speed Increasing to Greater Than Cut-Out. Instantaneous Reading: This event was documented in November 2008. Figure 6 shows the turbine shutting down for an instantaneous wind speed reading of more than $25 \mathrm{~m} / \mathrm{s}$ as the rotor speed and power fall to zero. After approximately 20 minutes, the wind speed slowed and turbine auto-started without error. Behavior upon Average Reading: This event was captured in January 2009. The parameter for allowed wind speed averaged over 10 minutes before shutdown was changed from $20 \mathrm{~m} / \mathrm{s}$ to $10 \mathrm{~m} / \mathrm{s}$. The setting was changed while the turbine was operating and the wind speeds were greater than $10 \mathrm{~m} / \mathrm{s}$. The turbine came to a stop and the controller read, "wind > max."

Maintenance or Fault Conditions at Design Wind Speed or Greater. This event was observed in January 2009. The emergency-stop button on the side of the controller box was pressed and the mechanical brake was activated to stop the turbine. The error was cleared manually and the turbine started without error.

\section{Emergency Shutdown from Any Operating Condition During Operation}

Emergency Stop in Wind Speeds Less Than Design Wind Speed $(10.5 \mathrm{~m} / \mathrm{s})$. This event was observed in January 2009. The wind speeds were between $7 \mathrm{~m} / \mathrm{s}$ and $10 \mathrm{~m} / \mathrm{s}$ when the emergency-stop button on the side of the controller box was pressed. The mechanical brake stopped the wind turbine within 2 to 3 seconds.

Emergency Stop at Design Wind Speed or Greater. This event was observed in January 2009. The wind speeds were between $20 \mathrm{~m} / \mathrm{s}$ and $25 \mathrm{~m} / \mathrm{s}$ when the emergency-stop button on the 
side of the controller box was pressed. The mechanical brake slowed the wind turbine to a stop within 2 to 3 seconds.

Behavior Upon Automatic Shutdown from Over Speed at Design Wind Speed or Greater. This event was observed in January 2009. While the turbine was operating, the setting for maximum rotor speed temporarily was changed to $59 \mathrm{rpm}$ (normally $66 \mathrm{rpm}$ ). As soon as the setting was changed, the mechanical brake brought the wind turbine to a stop and the controller read, "rotor over speed." The wind speeds were between $7 \mathrm{~m} / \mathrm{s}$ and $15 \mathrm{~m} / \mathrm{s}$.

Behavior Upon Automatic Shutdown from Generator Average Overcharge at Design Wind Speed or Greater. This event was captured in January 2009. If the average power for a 10minute period is greater than the controller setting, the turbine shuts down. To simulate this event, the setting in the controller was changed from $15 \mathrm{~kW}$ to $2 \mathrm{~kW}$. After the setting change, the turbine's mechanical brake was applied and the controller read, " $(\mathrm{G})$ power too high." It was confirmed through the data that the average power for the 10 minutes prior to shutdown was greater than $2 \mathrm{~kW}$. The wind speeds were between $12 \mathrm{~m} / \mathrm{s}$ and $14 \mathrm{~m} / \mathrm{s}$ at the time of the test.

\section{Behavior Upon Excessive Vibration}

The event was observed in February 2009. For this event, the mechanical brake was released and the vibration sensor in the turbine's nacelle was toggled manually. The mechanical brake was reapplied in response to the event and the controller read, "vibration error." The wind speeds were less than $5 \mathrm{~m} / \mathrm{s}$ during this event.

\section{Behavior Upon Loss of Load}

Response to Grid Outage. This event was observed in January 2009. The disconnect switch in the data shed was opened to simulate a grid outage and the turbine stopped within 2 to 3 seconds. After the switch was opened, the turbine voltage increased to $560 \mathrm{~V}$ before dropping to $0 \mathrm{~V}$. The wind speed was between $9 \mathrm{~m} / \mathrm{s}$ and $10 \mathrm{~m} / \mathrm{s}$ and the turbine was producing approximately $11 \mathrm{~kW}$. Figure 10 shows a time series of the event.

Response to Overvoltage. This event was observed in January 2009. The maximum gridvoltage setting was changed from 1.10 times the nominal voltage to 1.01 times the nominal voltage, to cause the turbine to fault at $484.8 \mathrm{~V}$ instead of $528 \mathrm{~V}$. The setting was changed when the voltage was approximately $488 \mathrm{~V}$, and the turbine stopped immediately. The controller read, "voltage high." The wind speeds were between $5 \mathrm{~m} / \mathrm{s}$ and $12 \mathrm{~m} / \mathrm{s}$.

\section{Turbine-Specific Checks}

Behavior Upon Rotor Over speed 10\%. This event was documented in August 2009. The maximum value for rotor speed setting in the controller was temporarily changed from the standard $66 \mathrm{rpm}$ to $50 \mathrm{rpm}$. The setting was changed while the turbine was parked. Figure 11 shows the turbine's rotor speed increase from $0 \mathrm{rpm}$ to approximately $49 \mathrm{rpm}$ when the brake was applied. The turbine came to a complete stop approximately 3 seconds after the brake was applied. The controller read, "rotor over speed." The wind speeds were between $4 \mathrm{~m} / \mathrm{s}$ and $6 \mathrm{~m} / \mathrm{s}$. 
Behavior Upon Rotor Over speed 15\%. This event was captured in May 2008. In case of a mechanical brake failure, the increased centripetal force causes the tip brakes to deploy at a rotor speed of approximately $15 \%$ greater than the nominal rotations per minute - or $69 \mathrm{rpm}$ - to aerodynamically stop the turbine. The rotor over speed $10 \%$ setting was increased to allow the tip brakes to deploy. One tip brake was deployed less than 1 second after the turbine reached $69 \mathrm{rpm}$. Figure 12 shows that the turbine came to a complete stop approximately 42 seconds after the tip brake was deployed. The wind speeds were between $2 \mathrm{~m} / \mathrm{s}$ and $6 \mathrm{~m} / \mathrm{s}$.

Behavior Upon Generator Instantaneous Overcharge. This event occurred in August 2009. The instantaneous generator overcharge setting temporarily was changed from $18 \mathrm{~kW}$ to $2 \mathrm{~kW}$ while the turbine was parked. Figure 13 shows the turbine shut down when the power exceeded $2 \mathrm{~kW}$. The controller read, "(G) peak power." The wind speeds were between $2 \mathrm{~m} / \mathrm{s}$ and $7 \mathrm{~m} / \mathrm{s}$.

Behavior Upon Generator Average Overcharge. This event was observed in January 2009. The average generator overcharge setting for 10 minutes was changed from $15 \mathrm{~kW}$ to $6 \mathrm{~kW}$. The turbine's mechanical brake was applied instantly and the controller read, "(G) power too high." It was confirmed through the data that, at the time the brake was applied, the average power for the prior 10 minutes was greater than $6 \mathrm{~kW}$. The wind speeds were between $7 \mathrm{~m} / \mathrm{s}$ and $17 \mathrm{~m} / \mathrm{s}$.

Behavior Upon Cable Twist. This event was observed in February 2009. The cables from the turbine nacelle are looped through a ring at the end of the cable twist arm. Excessive winding causes the cables to turn the ring and subsequently lift the cable twist arm. In this event, a sensor at the end of the cable twist arm is activated. While the turbine was parked, the cable twist arm located at the base of the tower was lifted to simulate a twisted cable. The controller error read, "cable twisted." In the case of an actual twisted cable, a service engineer from Gaia-Wind must unwind the cables. NREL staff did not attempt to manually twist the cables or to unwind them.

\section{Personnel Safety Provisions}

\section{Safety Instructions}

The turbine has three separate manuals - an installation manual, a user's manual, and a service manual. Generally, the installation and service manuals are used only by trained personnel and are not provided to the turbine owner. The user's manual states that only trained personnel should service or perform maintenance on their turbines, and safety requirements for the personnel are listed. The installation and service manuals list additional requirements for trained personnel regarding personal protective equipment, climbing, electrical work, mechanical maintenance, and wind conditions. All manuals include safety reminders and references throughout.

NREL staff checked the manuals to determine whether the safety instructions addressed requirements in accordance with the IEC small turbine design standard. NREL staff found the following. 
Disengage the load and/or energy sources: An isolation switch labeled "main switch" is located on the left-hand side of the controller box, although the user manual does not specifically indicate the location of this switch. The switch is shown in Figure 15.

Stop and secure the rotor: The service manual contained instructions on how to apply the brake the turbine from the controller and how to secure the rotor from the working basket.

Stop and secure the yaw mechanism: An anchor bolt is provided for locking the nacelle; this task must be performed from the working basket. Brief instructions on securing the yaw are given in the installation manual and the service manual.

Climb tower: The installation manual and service manual include descriptions of personal protective equipment that should be used when climbing the ladder, and also give some general guidelines. No manual includes specific instructions for climbing the tower or transitioning between the tower and the working basket.

\section{Climbing}

A ladder is attached to the turbine tower, and NREL personnel climbed using a point-to-point lanyard method. The nacelle manually must be yawed for workers to transition from the tower to the working basket. The yaw only can be locked from the working basket, therefore the transition to the basket can be difficult in wind speeds that are strong enough to yaw the turbine. The working basket can be entered from the tower through the bottom of the basket by lifting up one half of the platform and pushing it over the other half. There are nonstrengthened tie-off points inside the working basket. Exiting from the platform to the ladder presents a potential safety risk in that the turbine could yaw while personnel are exiting. Additionally, it might be difficult to manually yaw the turbine so that the working basket is facing the ladder.

\section{Standing Places, Platforms, and Floors}

The standing platform in the working basket is not secured through a lock or latch, and instead relies on gravitational pull to keep it in place. The platform in the working basket is a nonslip surface. To slide the platform back into place after entering the basket, however, NREL personnel had to stand on the working basket rails. The rails are not a nonslip surface and present a potential safety hazard.

\section{Electrical and Grounding System}

The power cables are exposed from the turbine tower to the controller where they terminate at a socket. The exposed cable presents a potential trip hazard, as shown in Figure 16. The socket termination shown in Figure 17 presents a potential safety hazard because it can be unplugged while the turbine is running. The grounding system consists of four ground rods embedded in the foundation and connected with a ground wire. The ground wire is connected to the tower and the turbine controller.

\section{Emergency-Stop Button}

The turbine has an emergency-stop button on the outside of the controller box, but it is not labeled. This button is used whenever the turbine must be shut down manually. Located on 
the outside of the controller box is a main switch for disconnecting the turbine from the grid; this switch is labeled "main switch." Figure 15 shows both the emergency-stop button and the main switch.

\section{Lock-Out/Tag-Out Provisions}

NREL provided a lockable switch between the grid and the turbine controller. The manufacturer does not provide this equipment or recommend that this type of equipment be installed.

\section{Interlock on Electrical Cabinets}

The controller does not have an interlock but it must be opened with a key provided by GaiaWind. This provides some protection from unauthorized access.

\section{Safety Signs}

Neither the turbine nor the controller had any warning signs affixed. NREL personnel labeled the controller, electrical panels, and disconnects, indicating the voltage levels of each.

\section{Presence and Functioning of Rotor Lock and Yaw Lock}

The turbine locks the rotor with a mechanical brake which can be activated using the controller, the emergency-stop button, the main switch, or a disconnect switch. The yaw mechanism can be secured from the working basket by installing an anchor bolt in the nacelle.

\section{Unauthorized Changing of Control Settings}

The controller settings are password-protected. There are two levels of access, one allows a user to view the turbine status and to reset user errors, and another level permits trained personnel to change settings and to reset external errors. To prevent the changing of the control settings or the resetting of external errors, users generally are not given the password for the higher-level access.

\section{Lighting Protection}

The turbine tower and controller are connected to a ground electrode intended to serve as lightning protection. During the test period no direct or nearby lightning strikes were observed.

\section{Dynamic Behavior}

The operation was observed by NREL personnel for at least 5 minutes at wind speeds of approximately $5 \mathrm{~m} / \mathrm{s}, 10 \mathrm{~m} / \mathrm{s}, 15 \mathrm{~m} / \mathrm{s}$, and $20 \mathrm{~m} / \mathrm{s}$ for a total observation period of at least 1 hour. NREL staff did not measure accelerations directly, however there were no apparent excessive vibrations in the tower. The turbine did not produce excessive noise, and yaw behavior appeared normal under all conditions. 


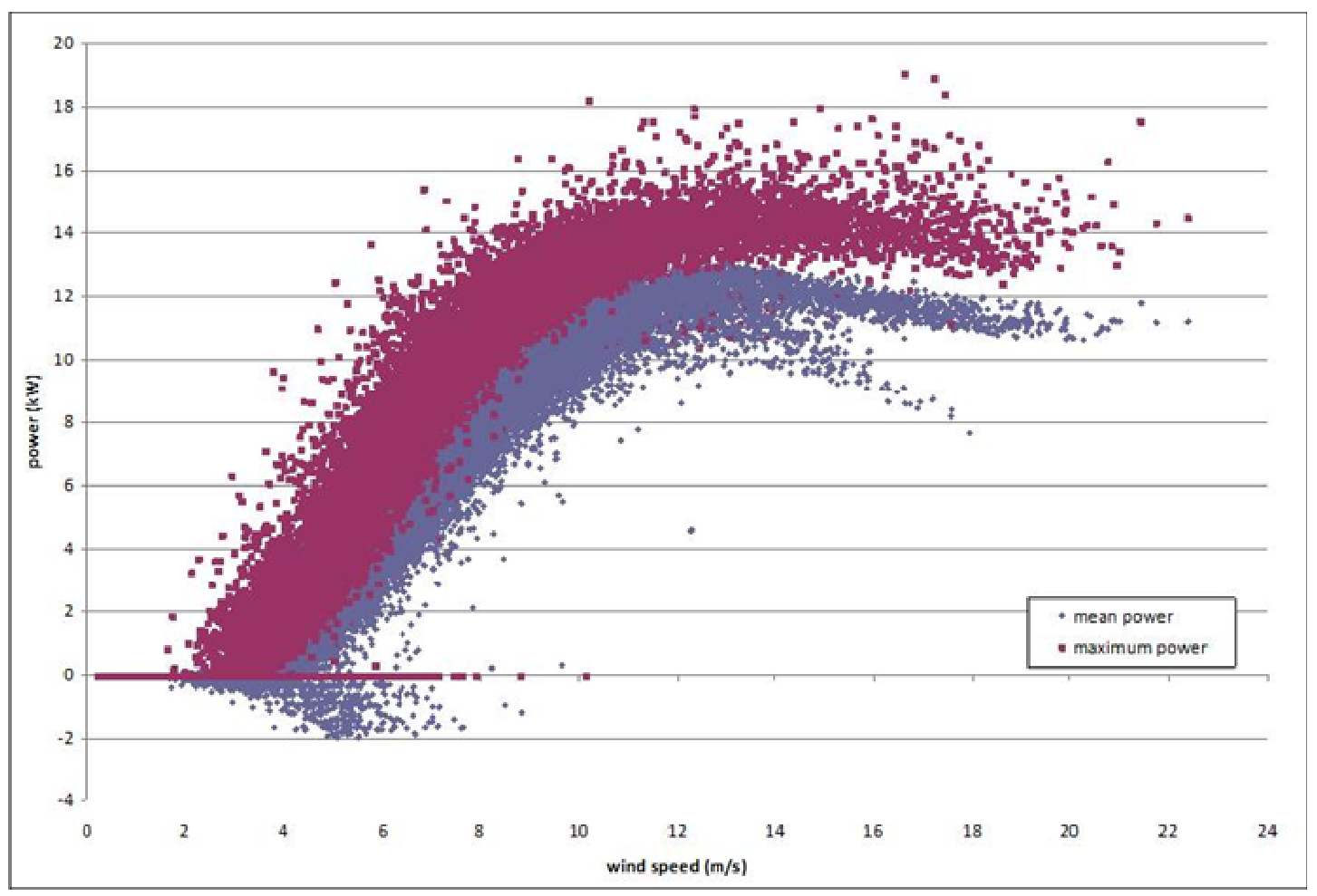

Figure 3. Power response to wind speed

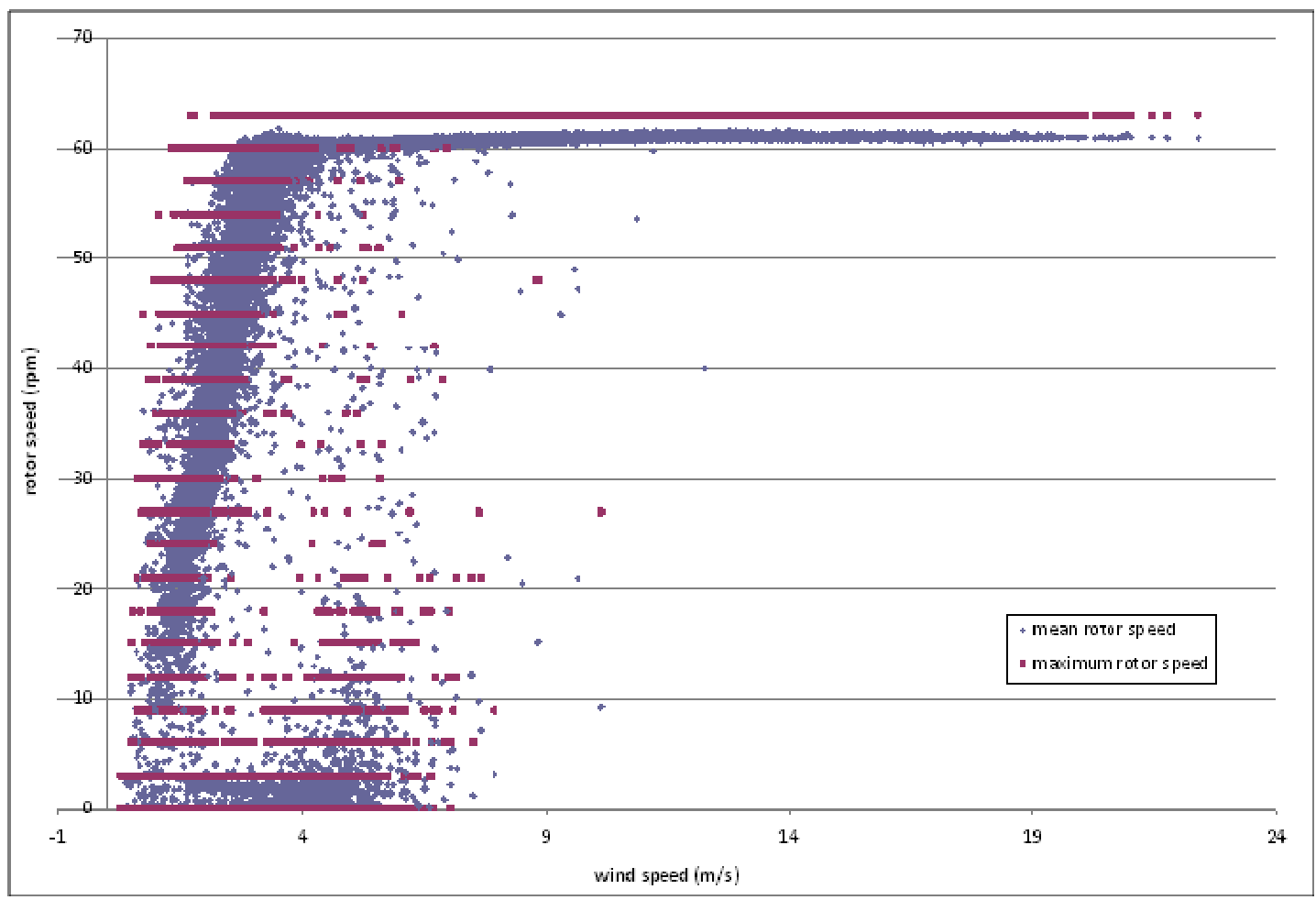

Figure 4. Rotor-speed response to wind speed 


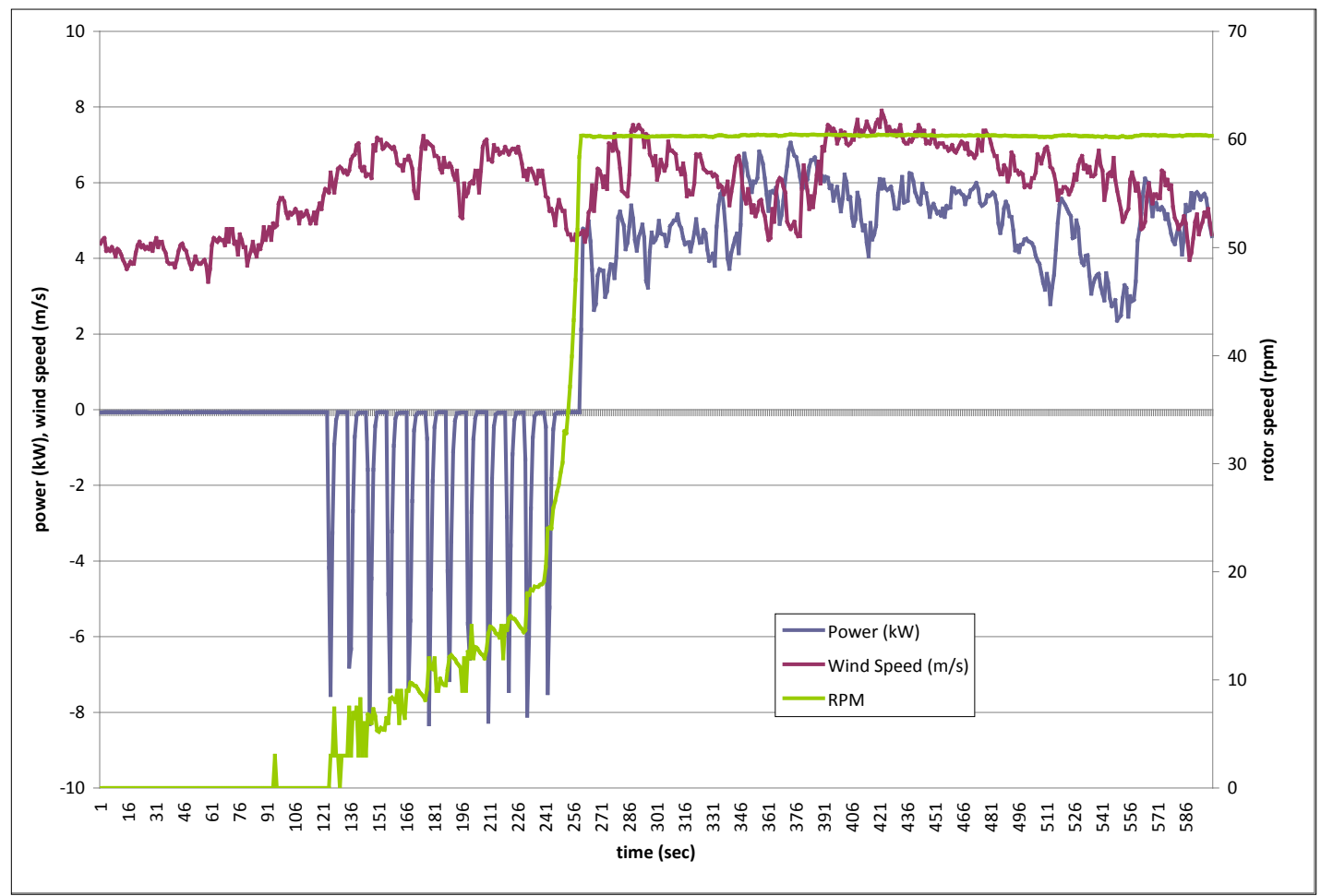

Figure 5. Normal start-up

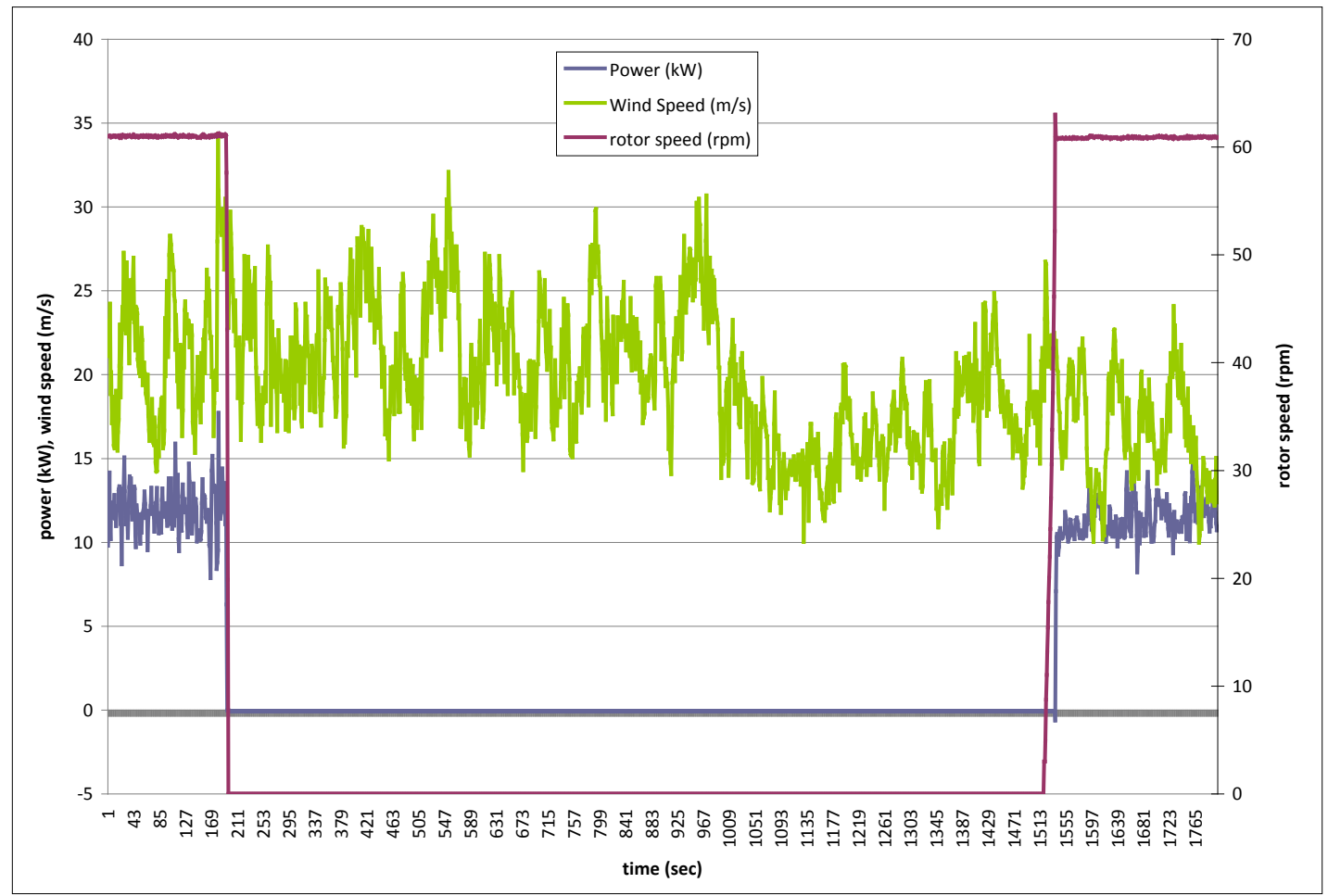

Figure 6. Turbine shutdown and auto-start after high-wind shutdown 


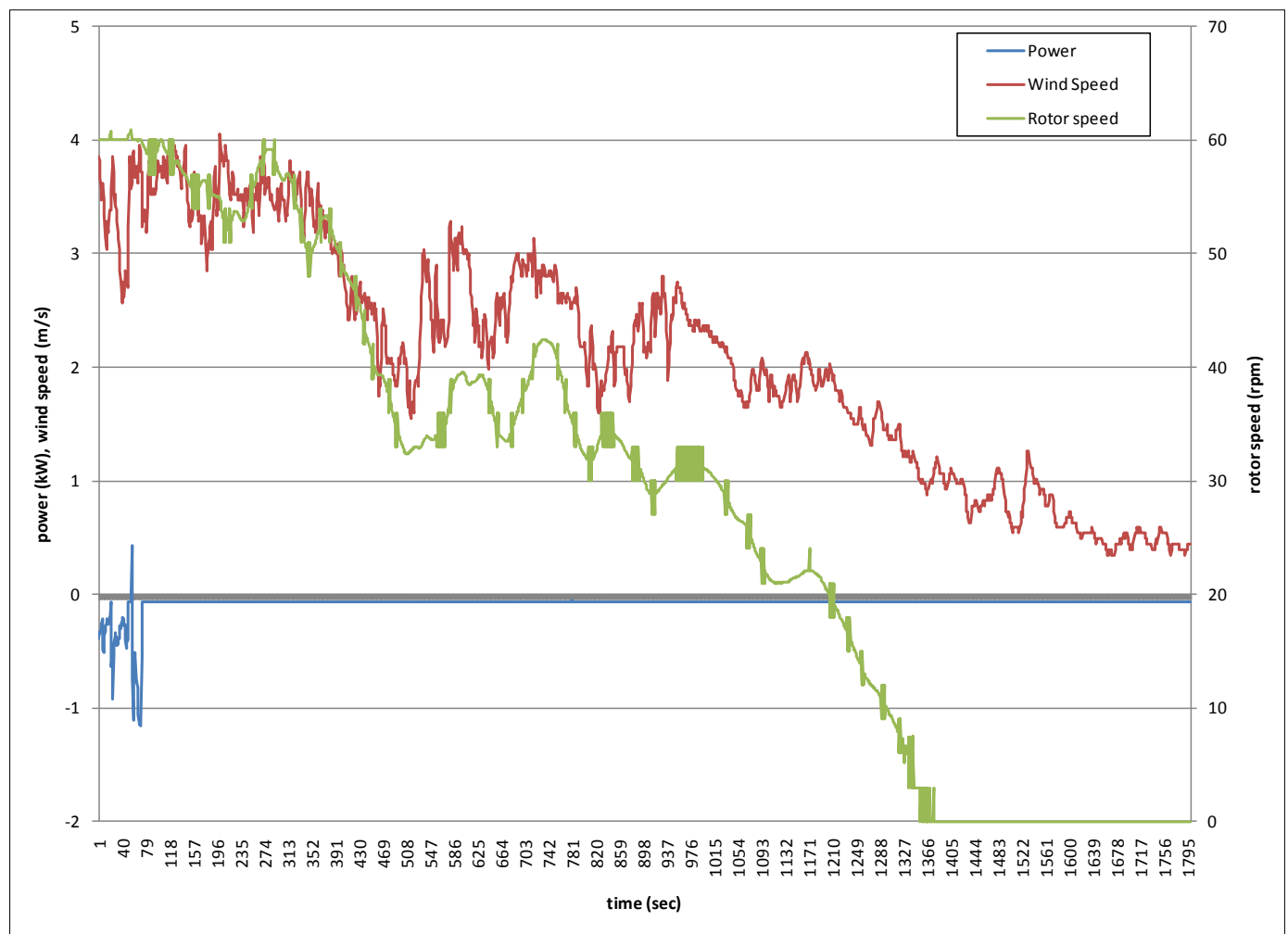

Figure 7. Normal shutdown in wind speeds decreasing to less than cut-in

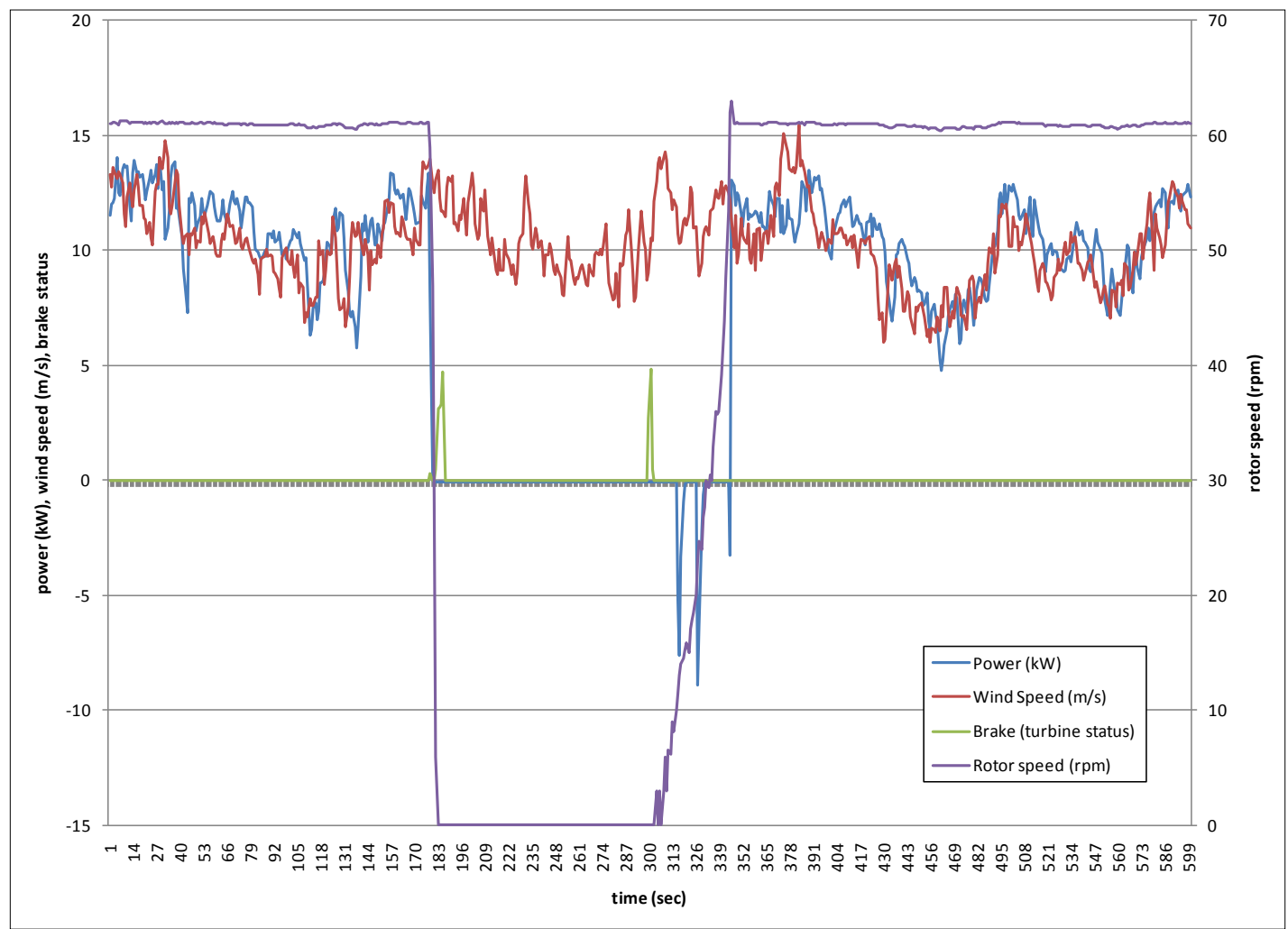

Figure 8. Automatic shutdown from over speed at design wind speed or greater 


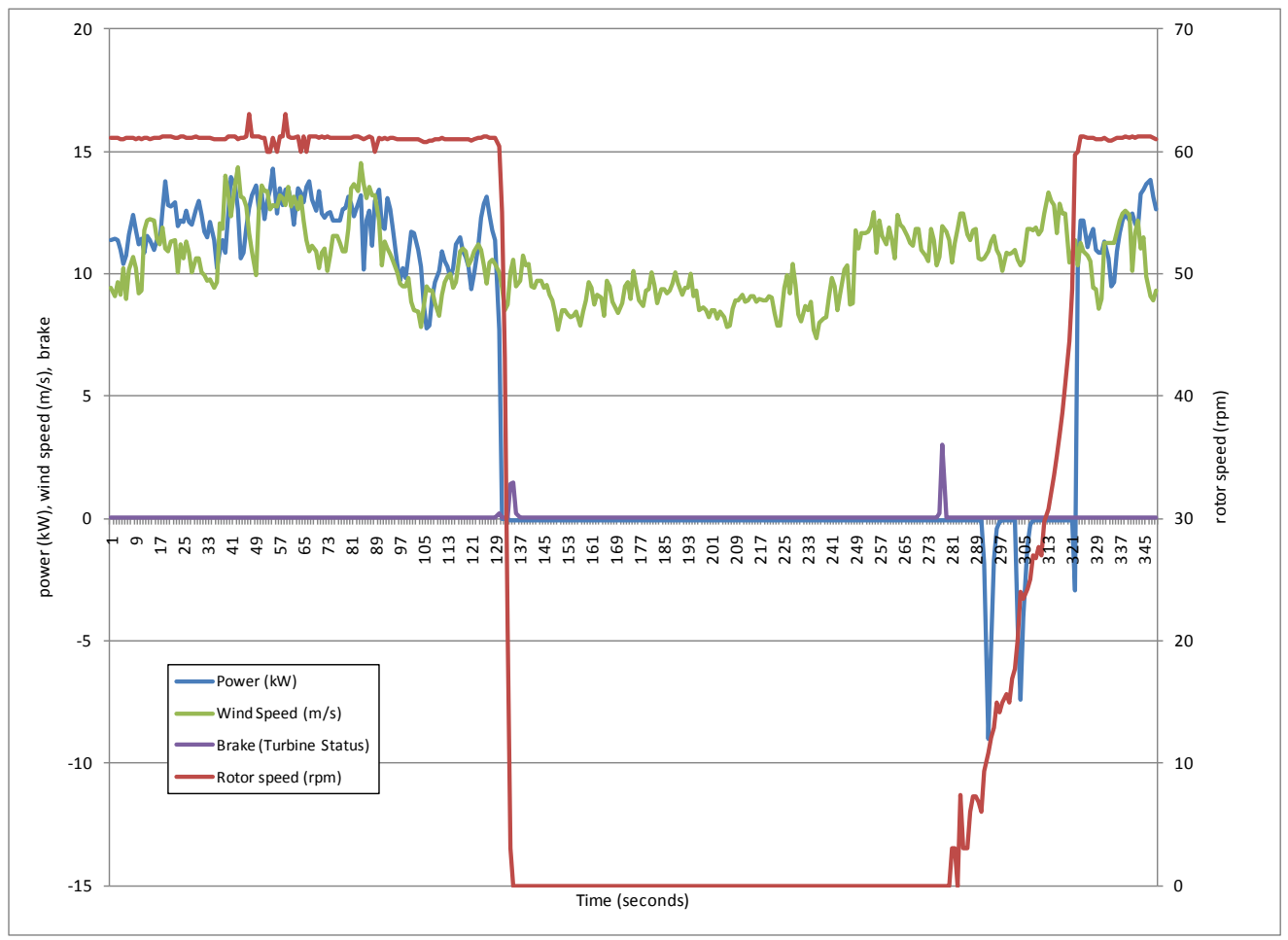

Figure 9. Normal start-up after fault clearance at design wind speed or greater

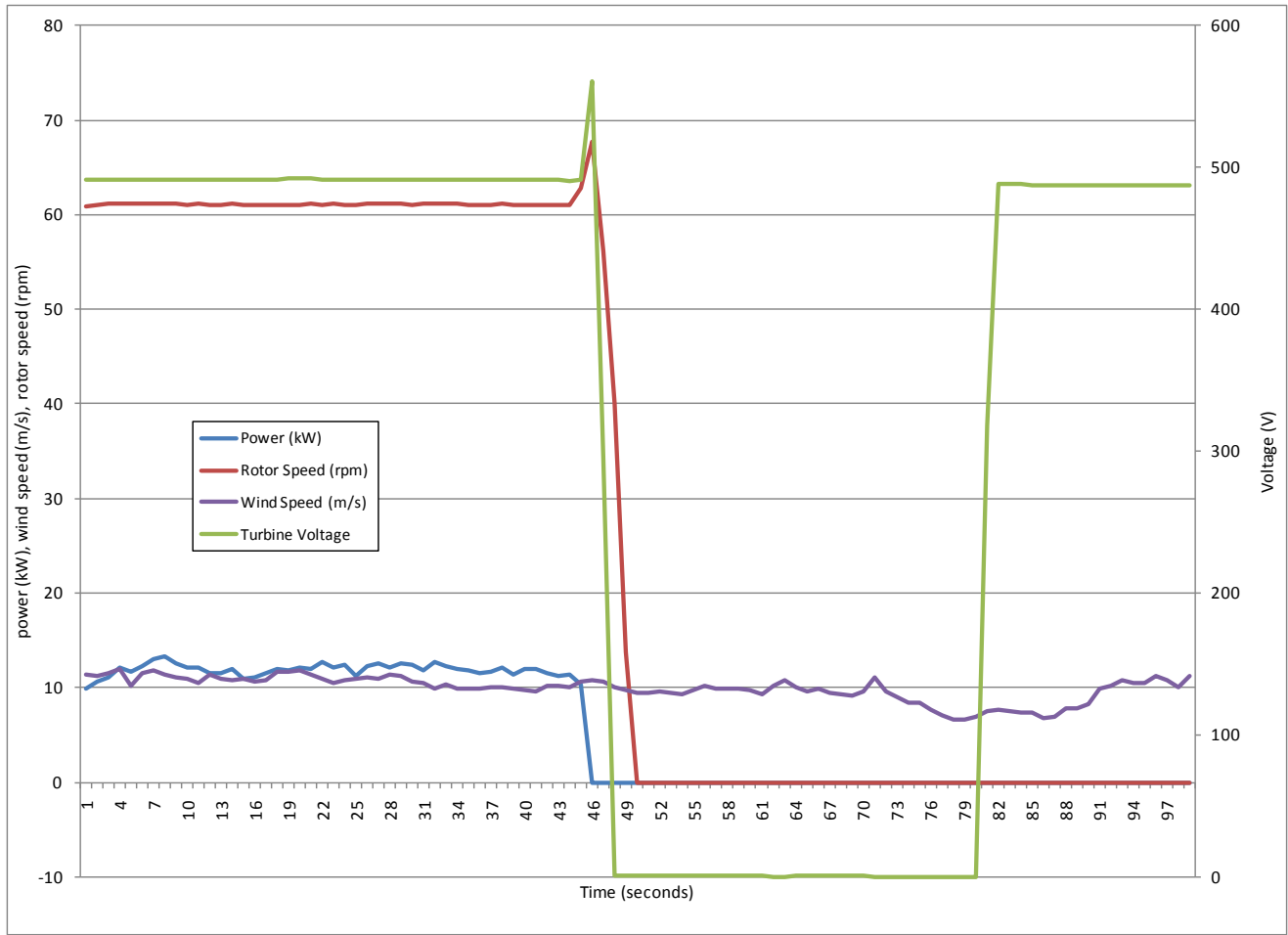

Figure 10. Automatic shutdown due to a grid outage 


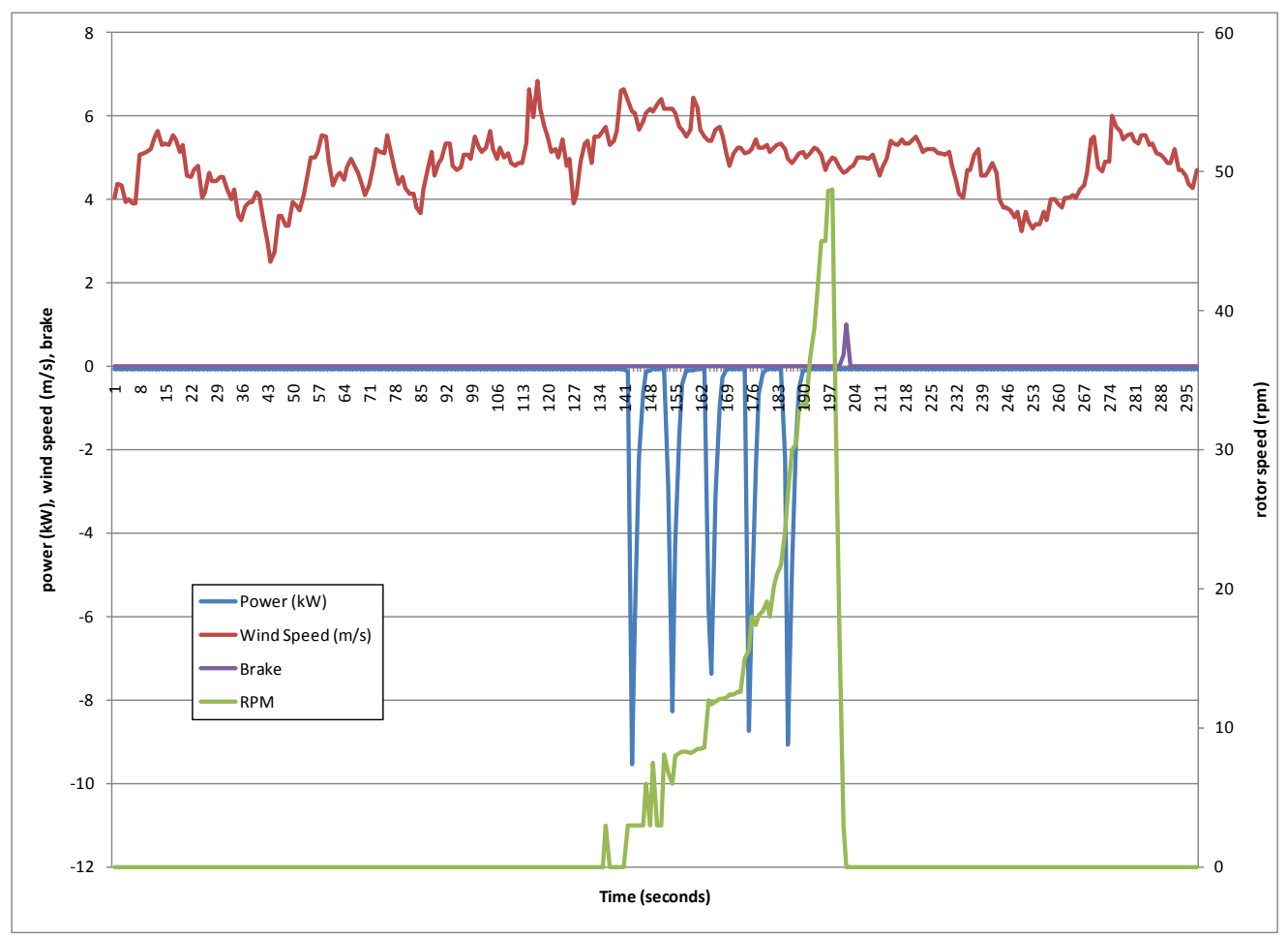

Figure 11. Automatic shutdown due to $10 \%$ rotor over speed

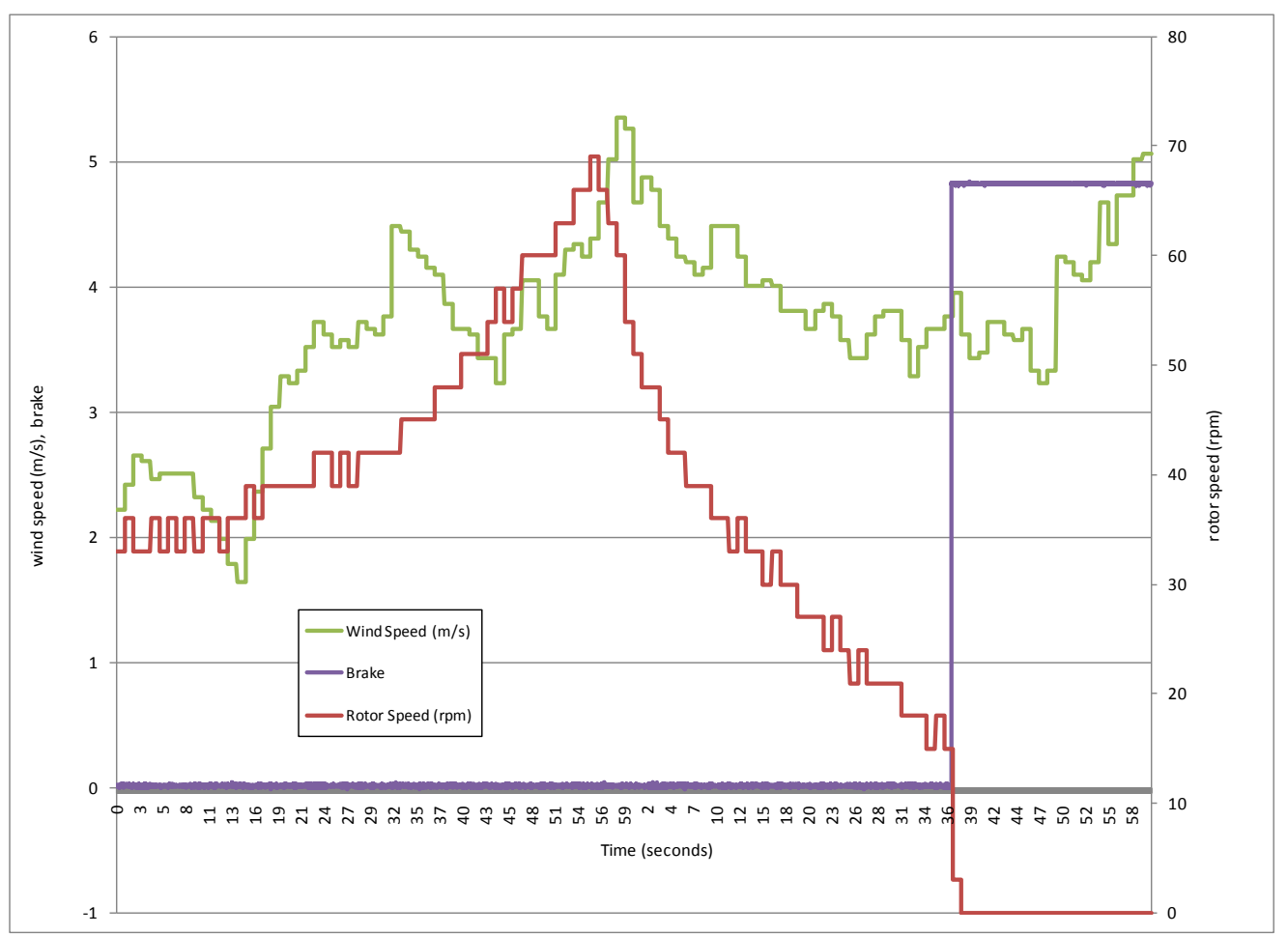

Figure 12. Shutdown using tip brakes due to $15 \%$ over speed 


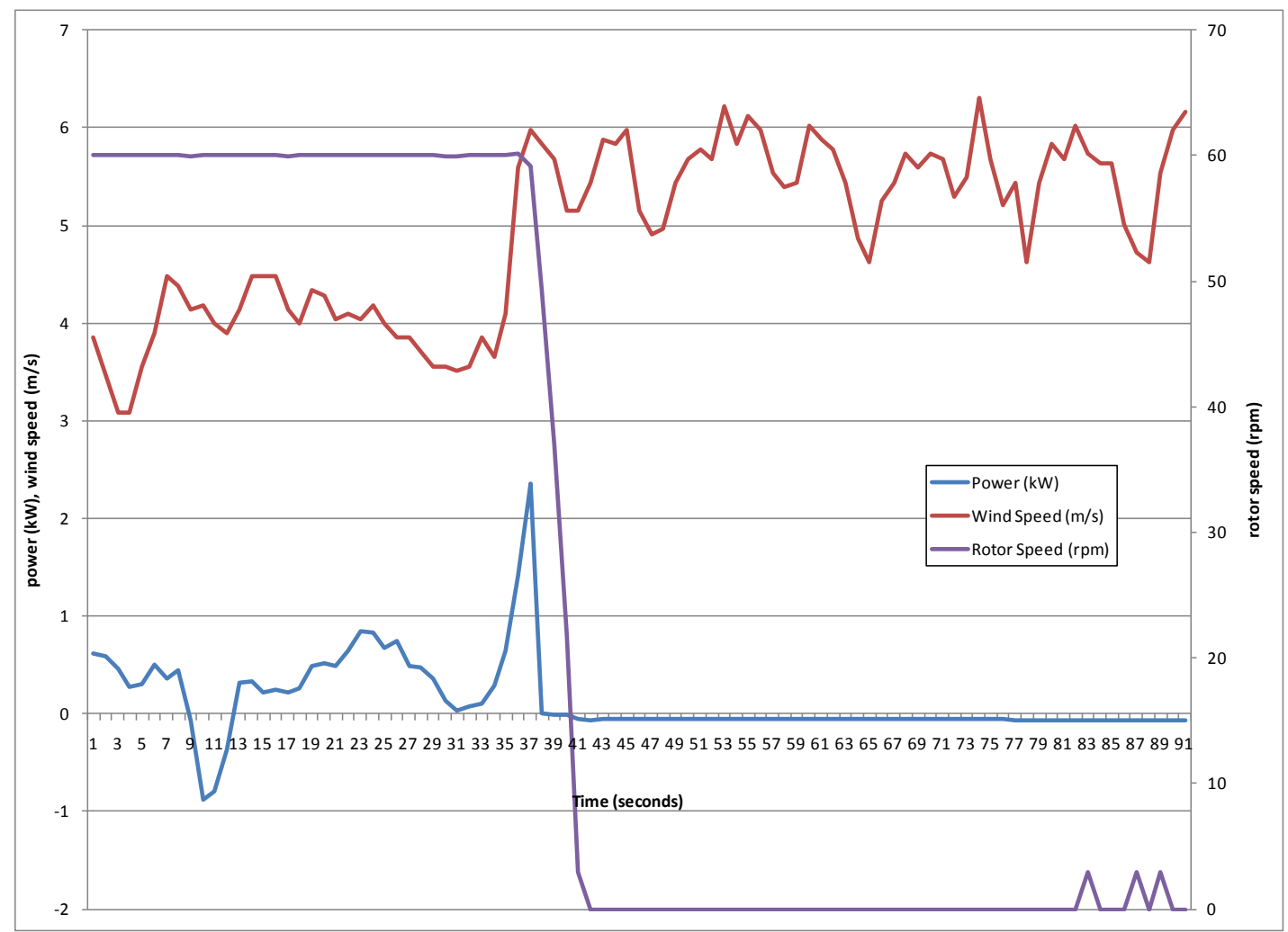

Figure 13. Automatic shutdown due to instant generator overcharge

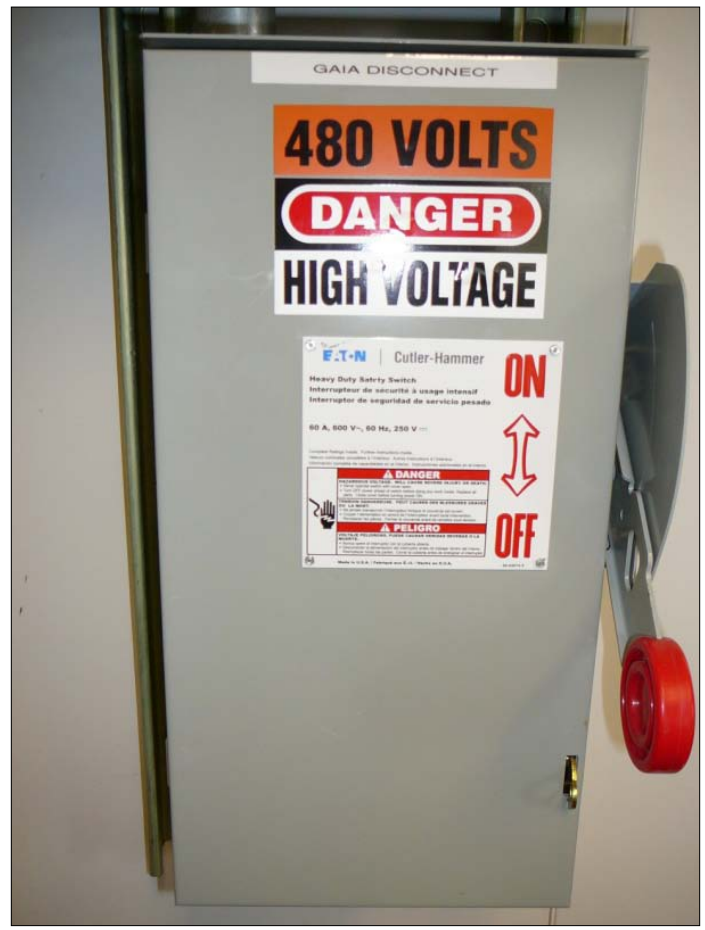

Figure 14. Gaia-Wind 11 kW disconnect switch 


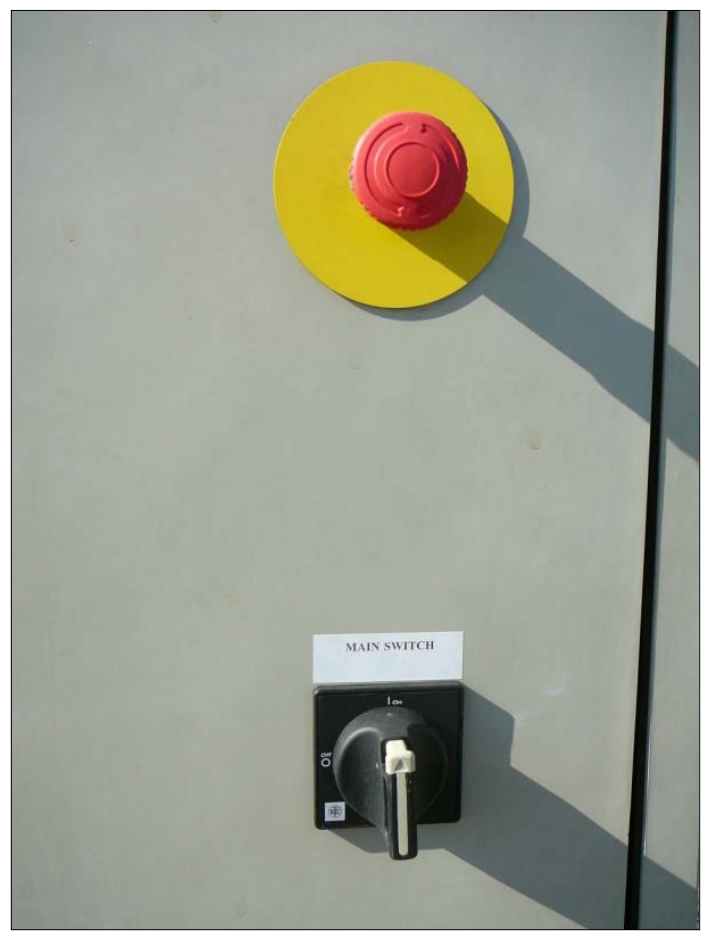

Figure 15. Gaia-Wind 11 kW emergency-stop button and main switch

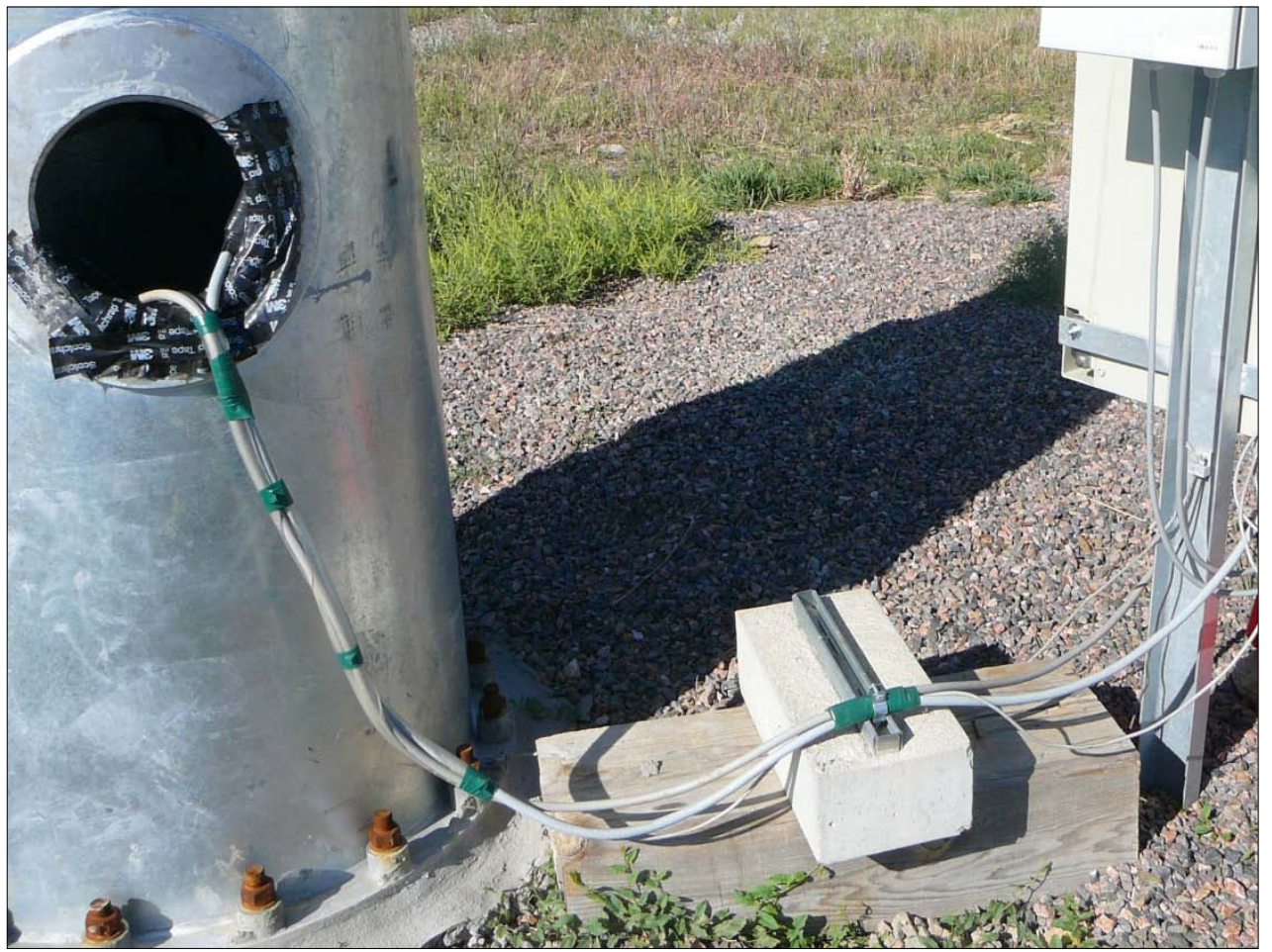

Figure 16. Power and instrumentation cables from turbine to controller 


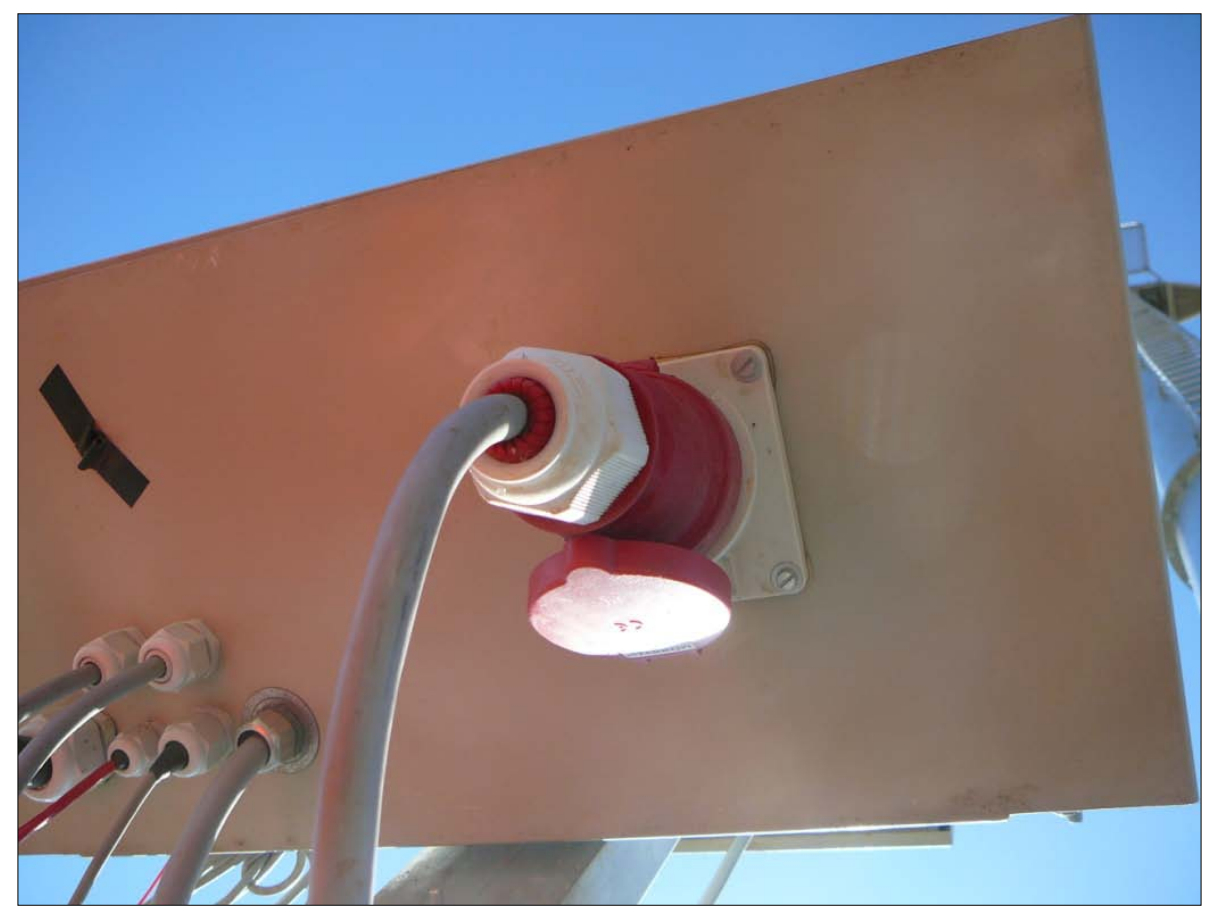

Figure 17. Power cable termination at controller

\section{Deviations and Exceptions}

\section{Deviations from the Standard}

There were no known exceptions to the standard, IEC 61400-2, for the test.

\section{Exceptions to the NWTC Quality Assurance System}

The data acquisition modules were used beyond the calibration due date. The modules were post-test calibrated and found to be in compliance within the specifications. Appendix A includes the post-test calibration sheets. 


\section{Appendix A. Instrument Calibration Sheets}

Branch \#: 5000

\section{NREL METROLOGY LABORATORY}

Test Report

Test Instrument: Multifunction Transducer

DOE \#: $03575 \mathrm{C}$

ModeI \#

: $D M T-1040 E$

$S / N: 06091046$

Calibration Date: $02 / 15 / 2008$

Due Date: $02 / 15 / 2010$

A. Set-Up for Total power Calibration:

A.1. Voltage is applied to Lines $1,2, \& 3=277.128 \mathrm{~V} @ 60 \mathrm{~Hz}$

A.2. Current is applied to $n=8$-TURNS through three current transformers

that are connected to Lines $1,2, \& 3$.

A.3. Analog Output-1 is measured across precision resistor $=250 \Omega$.

A.4. Flil Scale setting $=-15.796 \mathrm{KW}$ to $15.796 \mathrm{KW}$.

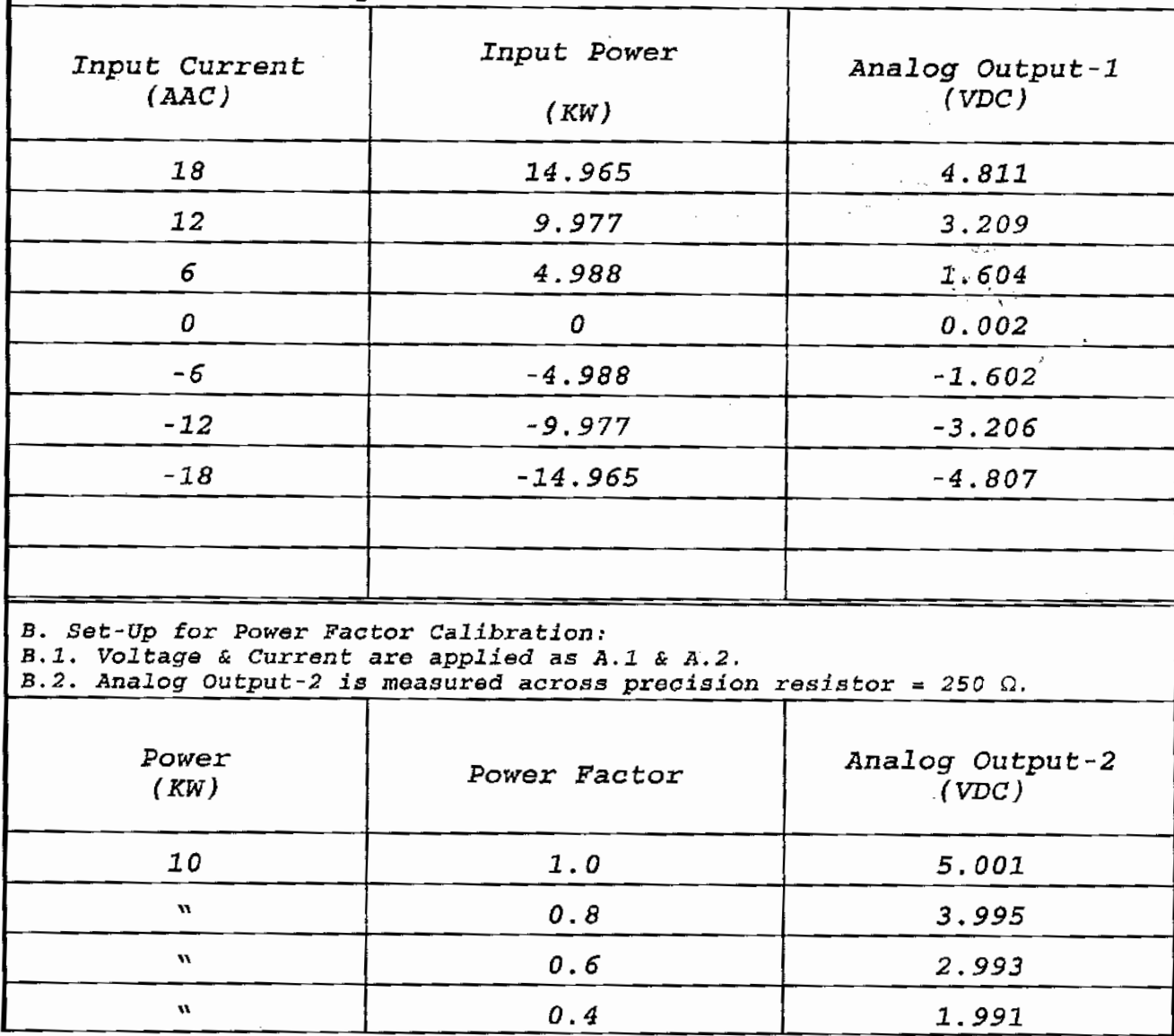

Page 1 of 2

Figure A.1. Power transducer calibration sheet 


\section{DEUTSCHER KALIBRIERDIENST DKD}

Kalibrierlaboratorium für Strömungsgeschwindigkeit von Luft Calibration laboratory for velocity of air flow

Akkreditiert durch die / accredited by the

Akkreditierungsstelle des DKD bei der PHYSIKALISCH-TECHNISCHEN BUNDESANSTALT (PTB)

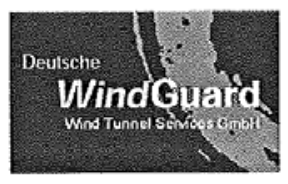

\section{Deutsche WindGuard \\ Wind Tunnel Services $\mathrm{GmbH}$ \\ Varel}

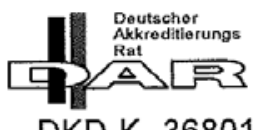

DKD-K- 36801
Kalibrierschein

Calibration Certificate

Cup Anemometer

Object

Hersteller

Manufacturer

Typ

Fabrikat/Serien-Nr. Serial number

Auftraggeber

Customer

Auftragsnummer

Order No.

Anzahl der Seiten des Kalibrierscheines Number of pages of the certificate

Datum der Kalibrierung

Date of calibration

24.07.2007

Thies Clima

D-37083 Göttingen

Body: 0707890

Cup: 0707890

Thies Clima
4.3350 .00 .000

D-37083 Göttingen

3

Dieser Kalibrierschein darf nur vollständig und unverändert weiterverbreitet werden. Auszüge oder Änderungen bedürfen der Genehmigung sowohl der Akkreditierungsstelle des DKD als auch des ausstellenden Kalibrierlaboratoriums. Kalibrierscheine ohne Unterschrift und Stempel haben keine Gültigkeit.

This calibration certificate may not be reproduced other than in full except with the permission of both the Accreditation Body of the DKD and the issuing laboratory. Calibration certificates without signature and seal are not valid.

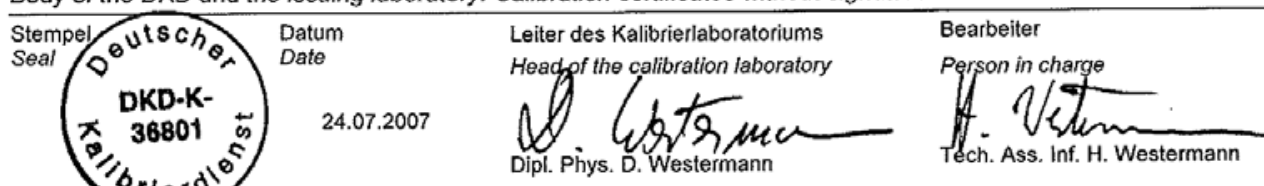

Deutsche WindGuard Wind Tunnel Services $\mathrm{GmbH}$

Oldenburger Str. 65

26316 Varel ; Tel. $++49(0) 445195150$ traceability to national standards, which realize recalibrated at appropriate intervals.
Kalibrierzeichen

Calibration label

Dieser Kalibrierschein dokumentiert die Rückführung auf nationale Normale zur Darstellung der Einheiten in Öbereinstimmung mit dem Internationalen Einheitensystem (SI).

Der DKD ist Unterzeichner der multi- lateralen Öbereinkommen der European co-operation for Accreditation (EA) und der International Laboratory Accreditation Cooperation (ILAC) zur gegenseitigen Anerkennung der Kalibrierscheine.

Für die Einhaltung einer angemessenen Frist zur Wiederholung der Kalibrierung ist der Benutzer verantwortlich.

This calibration certificate documents the the units of measurement according to the Intemational System of Units (SI).

The DKD is signatory to the multilateral agreements of the European co-operation for Accreditation (EA) and of the Intemational Laboratory Accreditation Cooperation (ILAC) for the mutual recognition of calibration certificates.

The user is obliged to have the object

Figure A.2. Primary anemometer calibration sheet 


\section{Wind Vane Calibration Report}

Calibration Laboratory:

National Wind Technology Center - Cert. Team

National Renewable Energy Laboratory

1617 Cole Boulevard

Golden, Colorado 80401

Customer:

National Wind Technology Center - Certification Team

National Renewable Energy Laboratory

1617 Cole Boulevard

Golden, Colorado 80401

Calibration Location:

National Wind Technology Center

Room 101, Building 256

Report Number: $\quad$ X4357-070913

Calibration Date:

13-Sep-07

Page: 1 of 1

Item Calibrated:

Manufacturer

Model

Met

Serial Number $\quad \mathrm{X} 4357$

Vane Material Aluminum

Condition Refurbished

Estimated Uncertainty: Inclinometer

Uncertainty

Uncertainty

$\begin{array}{rr}(\mathrm{deg}) & (\mathrm{deg}) \\ 0.10 & 0.33\end{array}$

0.33

Calibration by:

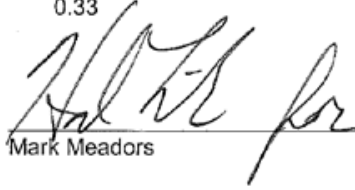

Procedure:

NWTC-CT: GI24-000613, Wind Vane Calibration

Deviations from procedure: $\quad$ Calibrated on $5 \mathrm{~V}$ range

Calibrated in Volts (not $\mathrm{mV}$ )

Results:

Slope: $\quad 71.12 \mathrm{deg} / \mathrm{V}$

Offset to boom: $\quad \mathbf{9 1 . 0 2} \mathrm{deg}$

Max error: $\quad 0.78$ deg

Traceability: $\quad$ Mfg \& Model $\begin{array}{r}\text { Serial } \\ \text { Number }\end{array}$

Inclinometer: Spi-Tronic 31-038-3 22-Mar-07 Voltmeter: $\quad$ Fluke743B 6965608 10-May-07

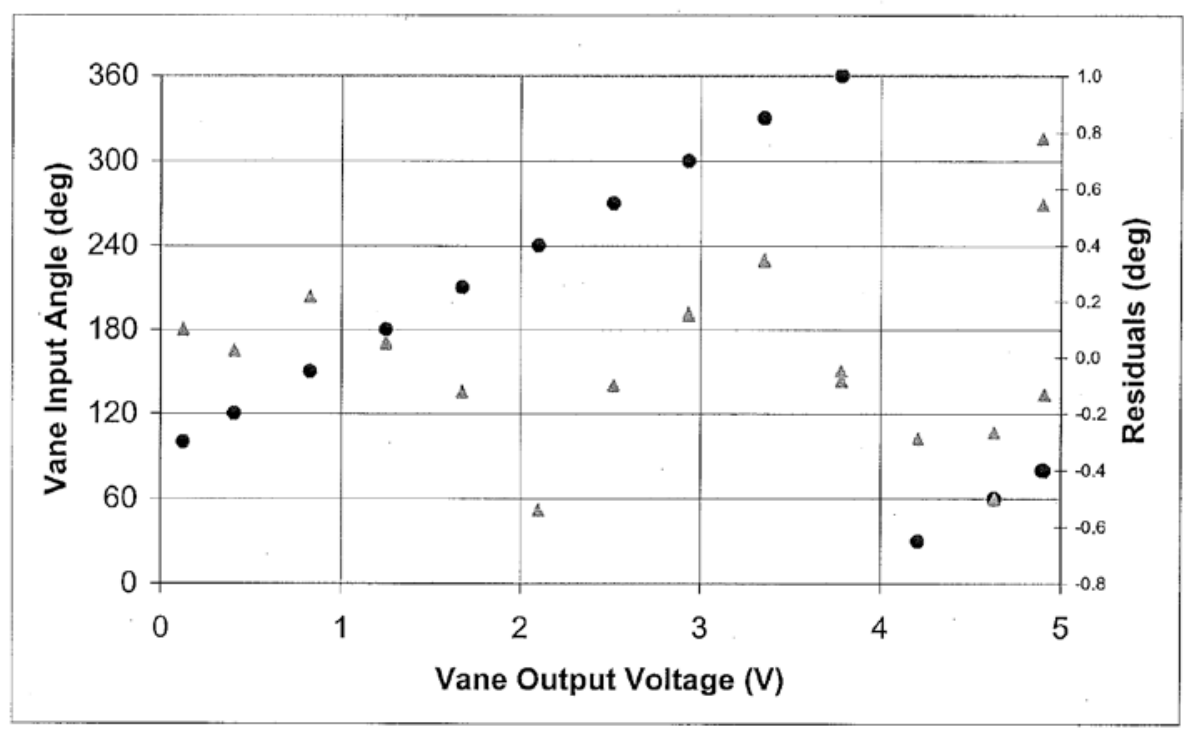

Figure A.3. Wind vane calibration sheet 


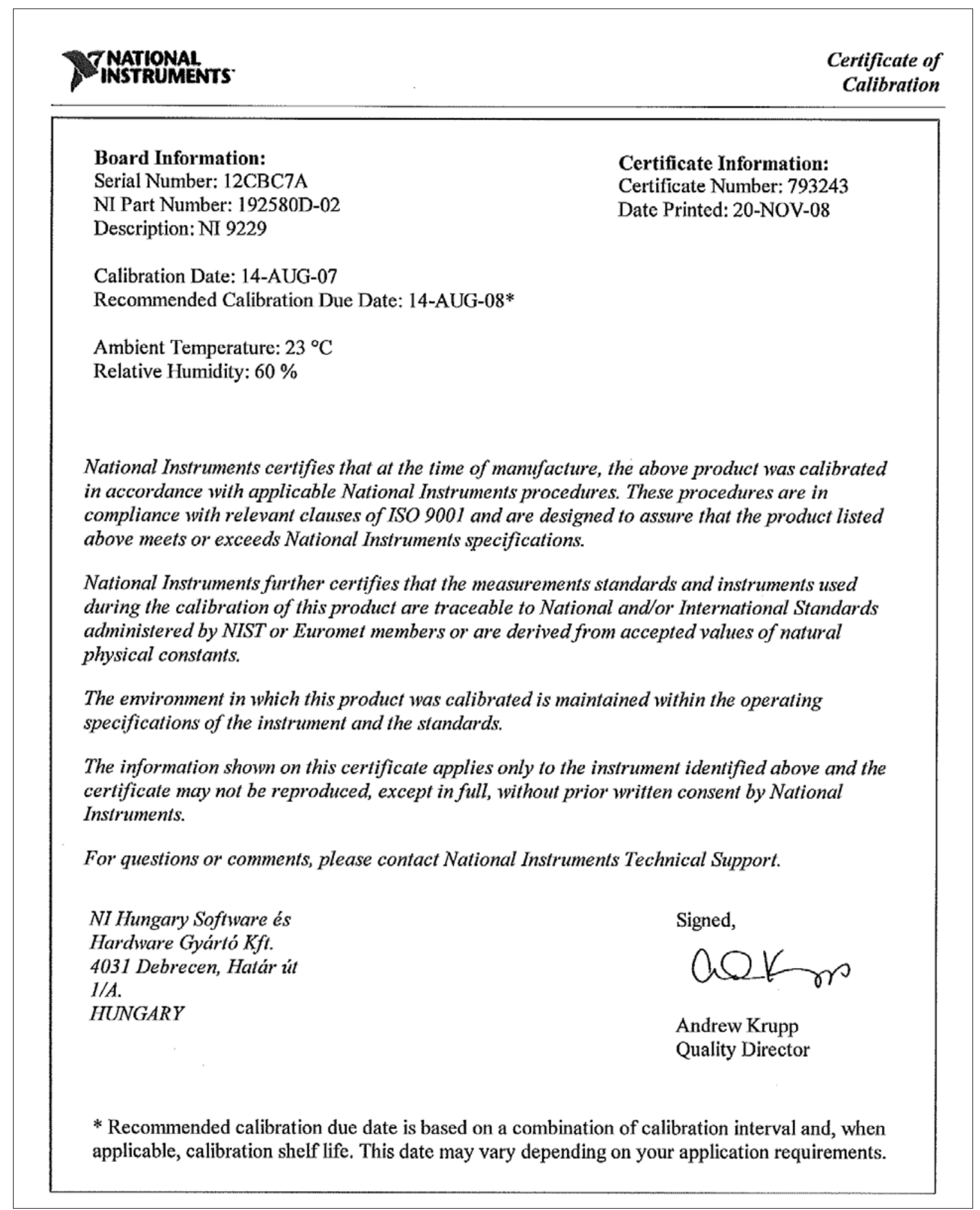

Figure A.4. National Instruments 9229 data-acquisition module calibration sheet I 


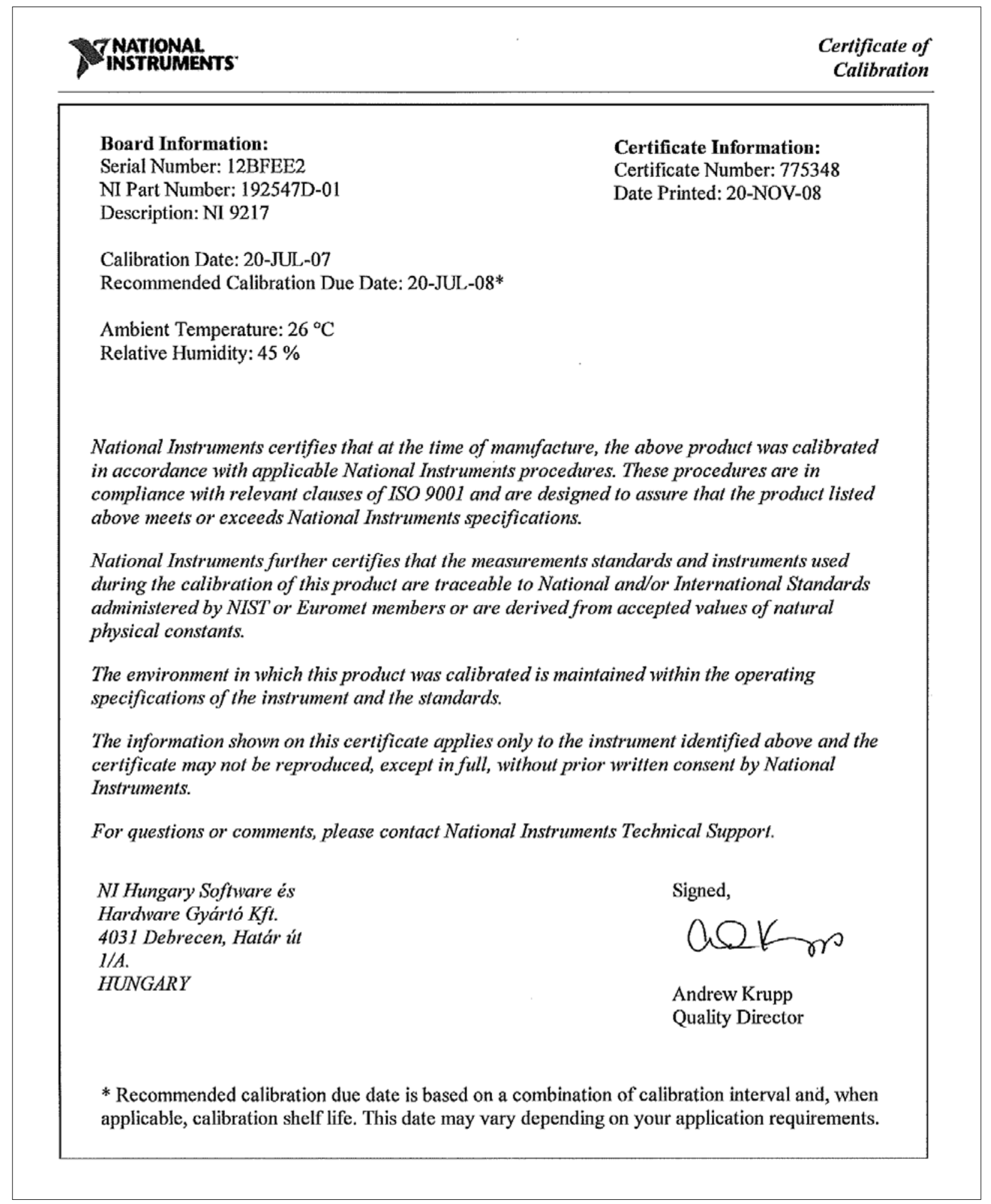

Figure A.5. National Instruments 9217 data-acquisition module calibration sheet I 
Board Information:

Serial Number: 12E9C99

NI Part Number: 193299F-01

Description: NI-9205

Calibration Date: 08-OCT-07

Recommended Calibration Due Date: 08-OCT-08*

Ambient Temperature: $23{ }^{\circ} \mathrm{C}$

Relative Humidity: $38 \%$
Certificate Information:

Certificate Number: 835019

Date Printed: 20-NOV-08

National Instruments certifies that at the time of manufacture, the above product was calibrated in accordance with applicable National Instruments procedures. These procedures are in compliance with relevant clauses of ISO 9001 and are designed to assure that the product listed above meets or exceeds National Instruments specifications.

National Instruments further certifies that the measurements standards and instruments used during the calibration of this product are traceable to National and/or International Standards administered by NIST or Euromet members or are derived from accepted values of natural physical constants.

The environment in which this product was calibrated is maintained within the operating specifications of the instrument and the standards.

The information shown on this certificate applies only to the instrument identified above and the certificate may not be reproduced, except in full, without prior written consent by National Instruments.

For questions or comments, please contact National Instruments Technical Support.

NI Hungary Software és

Hardware Gyártó Kft.

4031 Debrecen, Határ út

$1 / A$.

HUNGARY
Signed,

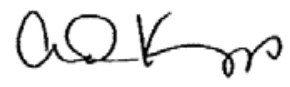

Andrew Krupp Quality Director

* Recommended calibration due date is based on a combination of calibration interval and, when applicable, calibration shelf life. This date may vary depending on your application requirements.

Figure A.6. National Instruments 9205 data-acquisition module calibration sheet I 


\section{Davis Calibration}

Company ID: 229037

NATIONAL INSTRUMENTS

11500 N. MOPAC EXPWY

ATTN. RMA DEPT

AUSTIN, TX78759

Instrument ID: 12CBC7A

Manufacturer. NATIONAL INSTRUMENTS

Description: 4-CHANNEL, $\pm 60 \mathrm{~V}, 24-\mathrm{BIT}$ SIMULTANEOUS ANALOG INPUT

Accuracy: Mir Specifications

Instrument Identification

\section{Certificate of Calibration}

3214337

Certificate Page 1 of 1

PO Number: 337683

Model Number: NI 9229

Serial Number: 12 CBC7A

Certificate Information

Reason For Service: CALIBRATION

Type of Cal: ACCREDITED 17025

As Found Condition: IN TOLERANCE

As Left Condition: LEFT AS FOUND

Procedure: NATIONAL INSTRUMENTS CAL EXECUTIVE REV 3.3.1

Remarks: Reference attached Data.

\author{
Technician: WAYNE GETCHELL \\ Cal Date 06May2009 \\ Cal Due Date: 06May2010 \\ Interval: 12 MONTHS \\ Temperature: $23.0 \mathrm{C}$ \\ Humidity. $44.0 \%$
}

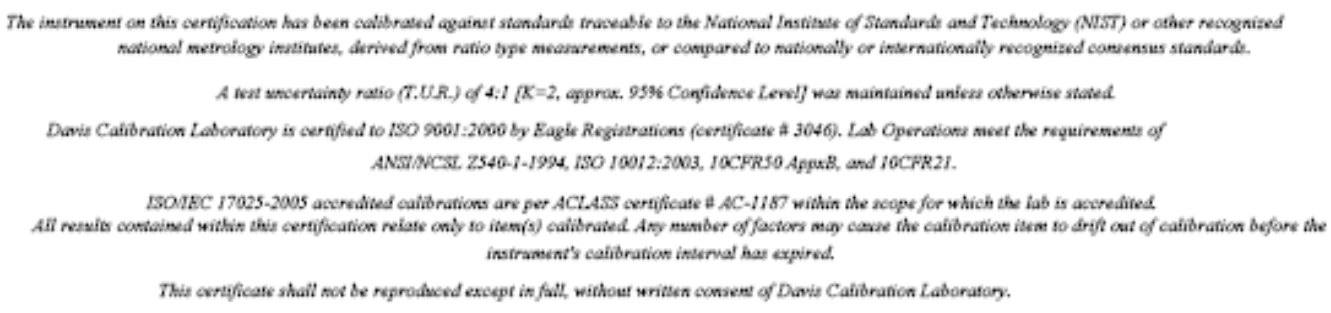

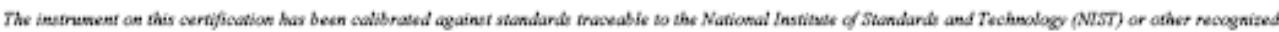

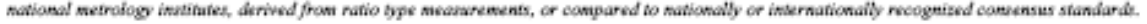

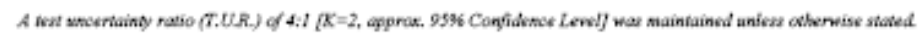

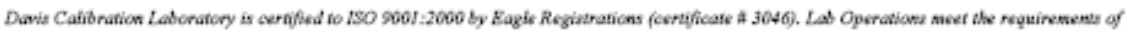

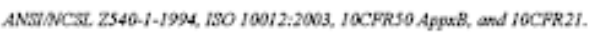

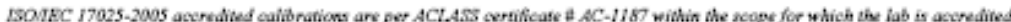

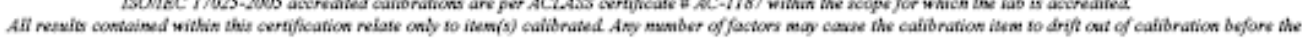
instrament's cafibnatios isternat hat expired.

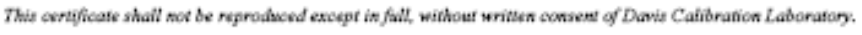

Approved By: VICTOR PENA

Service Representative

Calibration Standards

$\frac{\text { NIST Traceable\# }}{3143038} \frac{\text { Inst. ID\# }}{15-0271} \quad \frac{\text { Description }}{\text { MULTIFUNCTION CALBRATOR }} \quad \frac{\text { Model }}{5700 A} \quad \frac{\text { Cal Date }}{15 \text { Apr2009 Date Due }}$

Davis Calibration • 2324 Ridgepoint Drive, Suite D • Austin, TX 78754 • Phone: 800-365-0147 • Fax: 512-926-8450

Figure A.7. National Instruments 9229 data-acquisition module calibration sheet II 


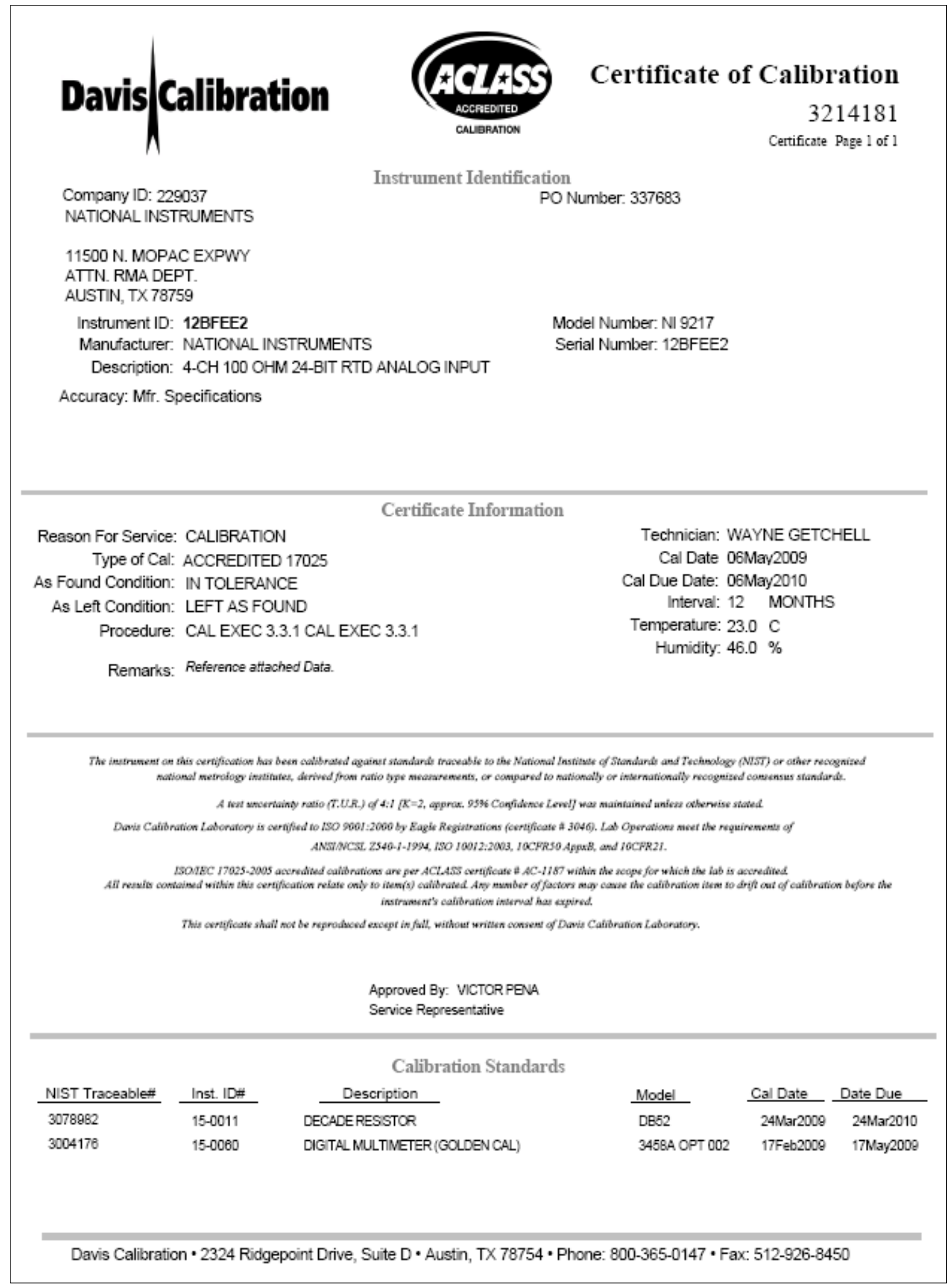

Figure A.8. National Instruments 9217 data-acquisition module calibration sheet II 


\section{Davis Calibration}

Company ID: 229037

NATIONAL INSTRUMENTS

11500 N. MOPAC EXPWY

ATTN. RMA DEPT.

AUSTIN, TX 78759

Instrument ID: 12E9C99

Manufacturer: NATIONAL INSTRUMENTS

Description: $32-\mathrm{CH} \pm 200 \mathrm{MV}$ TO $\pm 10 \mathrm{~V}, 16-\mathrm{BIT}, 250 \mathrm{KS} / \mathrm{S}$ ANALOG INPUT MODULE

Instrument Identification

PO Number: 337683

Model Number: NI 9205

Serial Number: 12E9C99

\section{Certificate of Calibration}

3214135

Certificate Page 1 of 1

Accuracy: Mir Specifications

Certificate Information

Reason For Service: CALIBRATION

Type of Cal: ACCREDITED 17025

As Found Condition: IN TOLERANCE

As Left Condition: LEFT AS FOUND

Procedure: NATIONAL INSTRUMENTS CAL EXECUTIVE REV 3.3.1

Remarks: Reference attached Data.

Technician: WAYNE GETCHELL

Cal Date 06May2009

Cal Due Date: 06May2010

Interval: 12 MONTHS

Temperature: $23.0 \mathrm{C}$

Humidity: $47.0 \%$

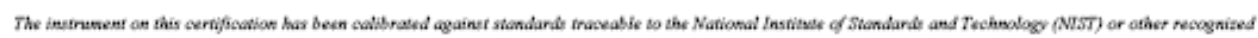

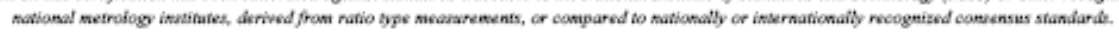

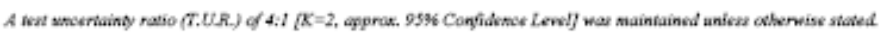

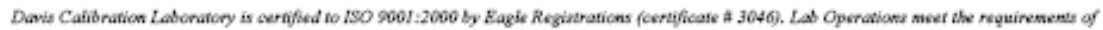

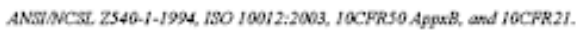

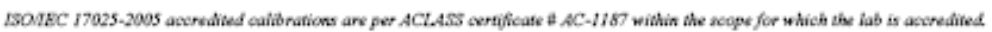

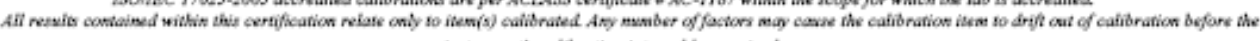
instrament's calibration istervat hat expired.

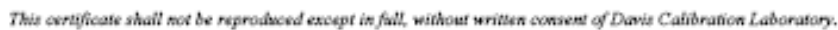

Approved By: VICTOR PENA

Service Representative

Calibration Standards

\begin{tabular}{|c|c|c|c|c|c|}
\hline NIST Traceable\# & Inst. ID\# & Description & Model & Cal Date & Date Due \\
\hline 3143038 & $15-0271$ & MULTIFUNCTION CALBRATOR & $5700 \mathrm{~A}$ & 15Apr2009 & $14 J u 12009$ \\
\hline
\end{tabular}

Davis Calibration • 2324 Ridgepoint Drive, Suite D • Austin, TX 78754 • Phone: 800-365-0147 • Fax: 512-926-8450

Figure A.9. National Instruments 9205 data-acquisition module calibration sheet II 


\section{REPORT DOCUMENTATION PAGE}

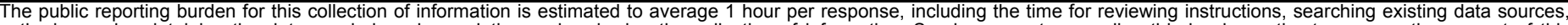

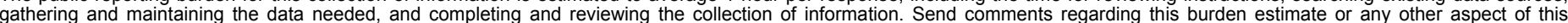

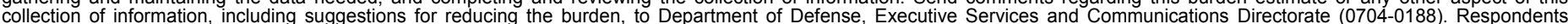

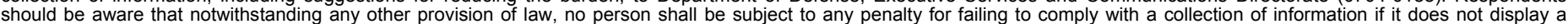

should be aware that notwithstandir

PLEASE DO NOT RETURN YOUR FORM TO THE ABOVE ORGANIZATION.

\begin{tabular}{l|l|l|l} 
1. REPORT DATE $(D D-M M-Y Y Y Y)$ & 2. REPORT TYPE & 3. DATES COVERED (FrOm - TO)
\end{tabular} January 2010

Technical Report

4. TITLE AND SUBTITLE

Wind Turbine Safety and Function Test Report for the Gaia-Wind 11-kW Wind Turbine 5a. CONTRACT NUMBER

DE-AC36-08-GO28308

5b. GRANT NUMBER

5c. PROGRAM ELEMENT NUMBER

5d. PROJECT NUMBER

NREL/TP-500-46724

5e. TASK NUMBER

WER94501

5f. WORK UNIT NUMBER
7. PERFORMING ORGANIZATION NAME(S) AND ADDRESS(ES)

National Renewable Energy Laboratory

1617 Cole Blvd.

Golden, CO 80401-3393
8. PERFORMING ORGANIZATION REPORT NUMBER

NREL/TP-500-46724

9. SPONSORING/MONITORING AGENCY NAME(S) AND ADDRESS(ES)

10. SPONSOR/MONITOR'S ACRONYM(S) NREL

11. SPONSORING/MONITORING AGENCY REPORT NUMBER

12. DISTRIBUTION AVAILABILITY STATEMENT

National Technical Information Service

U.S. Department of Commerce

5285 Port Royal Road

Springfield, VA 22161

13. SUPPLEMENTARY NOTES

14. ABSTRACT (Maximum 200 Words)

As part of the U.S. Department of Energy's (DOE) Independent Testing project, NREL conducted Safety and function testing on a Gaia-Wind 11-kW wind turbine mounted on an 18-m monopole tower. The objective was to 1) Verify whether the test turbine displays the behavior predicted in the design; 2) Determine whether provisions relating to personnel safety are properly implemented; and 3) Characterize the dynamic behavior of the wind turbine at rated wind speed and greater speeds.

15. SUBJECT TERMS

Gaia Small Wind Turbine; Safety and Function Test; 11kW wind turbine; small wind turbine; wind turbine designs

\begin{tabular}{l}
\hline \multicolumn{3}{|c|}{ 16. SECURITY CLASSIFICATION OF: } \\
\begin{tabular}{|l|l|l|}
\hline a. REPORT & b. ABSTRACT & c. THIS PAGE \\
Unclassified & Unclassified & Unclassified \\
& & \\
\hline
\end{tabular}
\end{tabular}

\begin{tabular}{l|l} 
17. LIMITATION & 18. $\begin{array}{l}\text { NUMBER } \\
\text { OF ABSTRACT } \\
\text { OF PAGES }\end{array}$ \\
UL &
\end{tabular}

19a. NAME OF RESPONSIBLE PERSON

19b. TELEPHONE NUMBER (Include area code) 